\title{
Flos de radice Iesse. A hermeneutic approach to the theme of the lily in Spanish Gothic painting of The Annunciation from patristic and theological sources Flos de radice Iesse. Aproximación hermenéutica al motivo del lirio en la pintura gótica española de La Anunciación a la luz de fuentes patrísticas y teológicas
}

\author{
José María SALVADOR GONZÁLEZ \\ Universidad Complutense de Madrid \\ jmsalvad@ucm.es
}

Recibido: $28 / 10 / 2013$

Aceptado: 05/12/2013

\begin{abstract}
Contradicting the superficial and unjustified conventional interpretation of the lily in the images of the Annunciation, this paper proposes two new deep theological explanations of that flower in this biblical episode. Based on the analysis of an abundant amount of quotes of the Church Fathers and medieval theologians, which show a wellestablished doctrinal tradition about this issue, we will try to demonstrate that the stem of lilies at the scene of the Annunciation symbolizes both the Mary's virginal divine motherhood and the supernatural human incarnation of God the Son, Christ. The current paper seeks also to relate these textual analyses of patristic and theological sources to twelve Spanish Gothic Annunciations which include a stem of lilies.
\end{abstract}

Key Words: Medieval art, Marian iconography, Spanish Gothic painting, Mariology, Christology, patrology, theology.

Resumen: A contracorriente de la superficial e injustificada interpretación convencional del lirio en las imágenes de La Anunciación, proponemos en este artículo dos nuevas interpretaciones profundamente teológicas de esa flor en ese episodio bíblico. Basándonos en el análisis de una abundante serie de citas de Padres de la Iglesia y teólogos medievales, las cuales evidencian una larga y consolidada tradición doctrinal en tal sentido, tratamos de mostrar que el ramo de lirios en la escena de la Anunciación simboliza tanto la virginal maternidad divina de María como la sobrenatural encarnación humana de Dios Hijo, Cristo. Nuestro estudio busca también relacionar esos análisis textuales de las fuentes patrísticas y teológicas con doce Anunciaciones góticas españolas que incluyen un ramo de lirios.

Palabras Clave: Arte medieval, iconografía mariana, pintura gótica española, mariología, cristología, patrística, teología.

Summary: 1. Proem: Recalling the Gospel story. 2. The motif of the stem of lilies in the Spanish Gothic painting of The Annunciation. 3. The meaning of the lily according to the experts in symbolism and iconography. 4. The flower in the stem of the Jesse's root, a symbolic prefiguration of the Mary's virginal divine motherhood and of the God the Son's incarnation. 5. Conclusions. Sources and bibliography.

\section{Proem: Recalling the Gospel story}

Despite its immense theological relevance within the history of salvation, the Annunciation of the angel to Mary is documented only in the Gospel of 

the lily in Spanish Gothic painting of The Annunciation from patristic and theological sources

Luke. ${ }^{1}$ As the evangelist points out, six months after Elizabeth conceived to John the Baptist, God sent the angel Gabriel to Nazareth to visit a virgin named Mary, wife of Joseph, of the David's lineage. ${ }^{2}$ Entering where the maiden was, the angel greeted her with these words: Ave gratia plena: Dominus tecum: Benedicta tu in mulieribus. ${ }^{3}$ Deeply disturbed by this laudatory greeting, incomprehensible to her, ${ }^{4}$ Mary received from Gabriel this reassuring message:

Non timeas Maria, invenisti enim gratiam apud Deum: ecce concipies in utero, et paries filium, et vocabis nomen eius Iesum: hic erit magnus, et Filius Altissimi vocabitur, et dabit illi Dominus Deus sedem David patris eius: et regnabit in domo Iacob in aeternum, et regni eius non erit finis. ${ }^{5}$

Surprised by such supernatural announcement, and asking how she could conceive without intercourse, ${ }^{6}$ the Virgin heard this comforting explanation by the angel: Spiritus sanctus superveniet in te, et virtus Altissimi obumbrabit tibi. Ideoque et quod nascetur ex te sanctum, vocabitur Filius Dei. ${ }^{7}$

Moved by such response of the heavenly herald -who, in proof that "there is nothing impossible for God", informed her that her cousin Elizabeth, sterile until then, was already in her sixth month of pregnancy ${ }^{8}$ - Mary expressed

1 Lk 1, 26-38. In Biblia Sacra iuxta Vulgatam Clementinam. Nova editio (logicis partitionibus aliisque subsidiis ornata a Alberto Colunga et Laurentio Turrado), Madrid, La Editorial Católica, Col. Biblioteca de Autores Cristianos, 12ª edición, 2005, p. 1011.

2 "In mense autem sexto, missus est angelus Gabriel a Deo in civitatem Galilaeae, cui nomen Nazareth, ad virginem desponsatam viro, cui nomen erat Ioseph, de domo David, et nomen virginis Maria." (Lk 1, 26-27. Ibid.).

3 "And he came to her and said, "Greetings, O favored one, the Lord is with you!"” (Lk 1, 28. Ibid.).

4 "Quae cum audisset, turbata est in sermone eius, et cogitabat qualis esset ista salutatio." "But she was greatly troubled at the saying, and tried to discern what sort of greeting this might be." (Lk 1, 29. Ibid.).

5 "And the angel said to her, "Do not be afraid, Mary, for you have found favor with God. And behold, you will conceive in your womb and bear a son, and you shall call his name Jesus. He will be great and will be called the Son of the Most High. And the Lord God will give to him the throne of his father David, and He will reign over the house of Jacob forever. His kingdom will never end!"' (Lk 1, 30-33. Ibid.).

6 "Dixit autem Maria ad angelum: Quomodo fiet istud, quoniam virum non cognosco?" "Then said Mary unto the angel, How shall this be, seeing I know not a man?" (Lk 1, 34. Ibid.).

7 "And the angel answered her, "The Holy Spirit will come upon you, and the power of the Most High will overshadow you; therefore the child to be born will be called holy, the Son of God."” (Lk 1, 35. Ibid. ).

8 "Et ecce Elisabeth cognata tua, et ipsa concepit filium in senectute sua: et hic mensis sextus est illi, quae vocatur sterilis: quia non erit impossibile apud Deum omne verbum." "And behold, your relative Elizabeth in her old age has also conceived a son, and this is the 
her absolute obedience to the Almighty's design, by proclaiming: Ecce ancilla Domini, fiat mihi secundum verbum tuum. ${ }^{9}$

These are the details and circumstances on the Annunciation registered in the New Testament. It is indeed symptomatic, in this regard, the fact that the St. Luke's canon story has been taken entirely -adding a few whimsical details in some cases - by the later apocryphal legends on the childhood of the Virgin Mary, whose three main models are the Proto Gospel of James (second-third centuries), ${ }^{10}$ the Gospel of the Pseudo Matthew (sixth century) $)^{11}$ and the Book on the Nativity of Mary (ninth century). ${ }^{12}$ Also the Dominican bishop Jacopo da Varazze expresses a similar fidelity to the Luke's substantial description in his widespread and influential Golden Legend $(1260-1298) \cdot{ }^{13}$ In the chapter devoted to the analyzed topic, ${ }^{14}$ Jacopo da Varazze does not add any data valuable for our aims, and merely "ornates" the Luke's story with some fabulous details extracted from the apocrypha and numerous citations of Church Fathers and theologians (particularly, St. Bernard of Clairvaux), while adding finally some arguments that, in his view, would justify the Messiah's announced advent and the Mary's divine motherhood.

Based essentially on the Luke's canonical text and, to a lesser extent, in some specific particulars of the apocryphal fables, the iconographic theme of The Annunciation to Mary ${ }^{15}$ is one of the most popular in the Christian

sixth month with her who was called barren. For nothing will be impossible with God." (Lk 1, 36-37. Ibid.).

9 "And Mary said, "Behold, I am the servant of the Lord; let it be to me according to your word."” (Lk 1, 38. Ibid.).

${ }^{10}$ Protoevangelio de Santiago. Bilingual text Greek / Spanish. In Aurelio de SANTOS OTERO, Los evangelios apócrifos, Salamanca, La Editorial Católica, Biblioteca de Autores Cristianos, 148, 2006, p. 130-170.

${ }^{11}$ Evangelio del Pseudo Mateo. Bilingual text Latin / Spanish. In SANTOS OTERo 2006: 172236.

${ }^{12}$ Libro de la Natividad de María. Bilingual text Latin / Spanish. In SANTOS OtERo 2006: 238-252.

${ }^{13}$ We use here the following Spanish version: Santiago de la VorAgine, La Leyenda Dorada (Traducción del latín: Fray José Manuel Macías), Madrid, Alianza Editorial, Col. Alianza Forma, 29, 1984, 2 vols.

${ }^{14}$ Santiago de la Voragine. "Capítulo LI. La Anunciación del Señor", La Leyenda Dorada, op. cit., vol. I: 211-216.

${ }^{15}$ We have already addressed this iconographic theme of The Annunciation in the following works: "La Virgen de la Anunciación, un paradigma de humildad en la doctrina y la imagen de la Edad Media“, Mirabilia. Electronic Journal of Antiquity \& Middle Ages, n 15, JulyDecember 2012, Institut d'Estudis Medievals, Universitat Autònoma de Barcelona, p. 189220; "La Anunciación", Capítulo 3 del libro José María SALVADOR GONZÁLEZ, Ancilla et Regina. Aproximaciones a la iconografía mariana en la Edad Media, Saarbrücken, Editorial Académica Española, 2012, 236 p. 
Byzantine and western European medieval art. ${ }^{16}$ Documented in a few, somewhat problematic images since the end of the second century -when a scene commonly interpreted as the first surviving expression of the Annunciation has been painted in the cubiculum IV of the Priscilla's roman catacomb ${ }^{17}$-, this item was diffused with great abundance especially from the fifth-sixth centuries in many mosaics, miniatures, ivories, and carvings in stone and ceramic. ${ }^{18}$

After starting its development through formulas of relative simplicity in compositional and eidetic means, the subject got a progressive morphological complexity and an increasingly sophisticated conceptualization from the eleventh century, through strange symbolisms and metaphors, in particular, during the Late Middle Ages. According to the approach of some experts, the outstanding propaganda success and the profound immersion of this iconographic theme in the slant of the analogy are explained, above all, for doctrinal reasons, stimulated by the progressive devotion to the Virgin, in perfect parallel with the deepening and conceptual refinement of Mariology, in direct and indissoluble link with the hyper-development of Christology.

In analyzing the multiple interpretations of the Annunciation produced by the Byzantines and Europeans artists -prominent among the latter with singular brilliance those from Italy, Spain and Flanders-, some prestigious iconographers, as Louis Réau ${ }^{19}$ and Gertrud Schiller, ${ }^{20}$ carefully analyze the elements which configure this artistic image. They deal with the thorough description of its protagonists (Mary and the angel Gabriel), the situations, postures, attitudes and attributes that distinguish them, its architectural setting, habitat, appliances and scenic accessories, not forgetting in some paintings the presence of other actors, such as the Holy Spirit in the form of a dove, God the Father leading the whole episode, and even sometimes other angels accompanying Gabriel.

However, despite the care with which the experts describe these significant elements, they seem to neglect an "accessory", whose repetitive presence almost a constant - in the late medieval European Annunciations allows us to suspect that some symbolism of essential relevance underlies in it: the stem of lilies, which sometimes the archangel Gabriel carries in his hands or, more often, is located in a vase next to Mary.

\footnotetext{
${ }^{16}$ For a clear summary of the differences between the Byzantine and Western Annunciations, see Gertrud SCHILLER, Iconography of Christian Art. Volume I (Translated by Janet Seligman), London, Lund Humphries, 1971, p. 33-52.

${ }^{17}$ LECLERCQ, Henri, "II. L'Annonciation dans l'art", Dictionnaire d'Archéologie Chrétienne et de Liturgie, Tome 1, ${ }^{\mathrm{e}}$ Partie, Paris, Librairie Letouzey et Ané, 1924, col. 2255-2256.

${ }^{18}$ LECLERCQ, Henri, Ibid., col. 2257-2266.

${ }^{19}$ Louis REAU, Iconographie de l'art chrétien. Tome Second, Iconographie de la Biblie. II, Nouveau Testament, Paris, Presses Universitaires de France, 1957, p. 174-194.

${ }^{20}$ Gertrud SCHILLER, op. cit., p. 33-52.
} 


\section{The motif of the stem of lilies in the Spanish Gothic painting of The Annunciation.}

To tell the truth, this symbolic floral element was included by most of the late medieval European artists in their respective pictures of the Annunciation. This is evidenced, for example, in so illustrative Italian Trecento and Quattrocento Annunciations such as the painted by Pietro Cavallini in Santa Maria in Trastevere in Rome, ${ }^{21}$ Duccio in The Maestà of the Siena Cathedral, ${ }^{22}$ Simone Martini in the Altarpiece of the Annunciation with two Saints, in the Galleria degli Uffizi, ${ }^{23}$ Bernardo Daddi in a panel of the Musée du Louvre, ${ }^{24}$ Masolino da Panicale in the Roman church of St. Clement, ${ }^{25}$ Fra Filippo Lippi in eight different versions, ${ }^{26}$ Benozzo Gozzoli in the Pinacoteca Vaticana, ${ }^{27}$ Sandro Botticelli in his two interpretations in Florence ${ }^{28}$ and New York, ${ }^{29}$ Domenico Ghirlandaio in the florentine Tornabuoni Chapel, ${ }^{30}$ Fra

\footnotetext{
${ }^{21}$ Pietro CAVAllini, The Annunciation, c. 1296-1300, mosaic, apse of the Basilica di Santa Maria in Trastevere, Rome.

${ }^{22}$ DuCCIO DI BUONINSEGNA, The Annunciation, 1308-1311, tempera and gold on wood, $43 \mathrm{x}$ $44 \mathrm{~cm}$, panel of the front predella of La Maestà in the Siena Cathedral (now in the National Gallery of London).

${ }^{23}$ Simone MARTINI, The Annunciation, 1333, tempera and gold on wood, 184 x $210 \mathrm{~cm}$,
} central panel of the altarpiece The Annunciation with two saints (painted with the assistance of Lippo Memmi), Galleria degli Uffizi, Florence.

${ }^{24}$ BERNARDO DADDI, The Annunciation, c. 1335, tempera and gold on wood, 43 x $70 \mathrm{~cm}$, Musée du Louvre, Paris.

${ }^{25}$ Masolino DA PANiCAle, The Annunciation, 1425-1431, fresco in the triumphal arch, Cappella del Sacramento (Cappella Castiglione), San Clemente, Rome.

${ }^{26}$ These eight Annunciations of FRA FILIPPO LIPPI are now dispersed in the Frick Collection of New York (1437-39, tempera on wood, 64 x $23 \mathrm{~cm}$ each panel), in the National Gallery of Art of Washington, DC (1435-40, tempera on wood, $100 \times 161 \mathrm{~cm})$, in the Galleria DoriaPamphili in Rome (c. 1445-50, tempera on wood, 117 x $173 \mathrm{~cm}$ ), in the Alte Pinakothek of Munich (c. 1443, wood, $203 \times 186 \mathrm{~cm}$ ), in the church of San Lorenzo in Florence (c. 1445, wood, $175 \times 183 \mathrm{~cm})$, in the National Gallery of London (1448-50, tempera on wood, $68 \mathrm{x}$ $152 \mathrm{~cm}$ ), in the Galleria Nazionale d'Arte Antica in Roma (The Annunciation with two kneeling donors, c. 1440, oil on wood, $155 \times 144 \mathrm{~cm}$ ), and in the Spoleto Cathedral (146769, fresco).

${ }^{27}$ Benozzo Gozzoli, L'Annunciazione di San Domenico, c. 1449, tempera on wood, $120 \mathrm{x}$ $140 \mathrm{~cm}$, Pinacoteca Communale, Narni.

${ }^{28}$ SANDRo BotTiCELli, The Annunciation, 1481, fresco, $243 \times 550 \mathrm{~cm}$ (originally in the entrance of the Hospital of San Martino della Scala, Florence). Galleria degli Uffizi, Florence.

${ }^{29}$ SANDRo BotTiCELLI, The Annunciation, c. 1485, tempera and gold on wood, 19,1 x 31,4 $\mathrm{cm}$, Metropolitan Museum of Art, New York.

${ }^{30}$ Domenico GHIRLANDAIO, The Annunciation, 1486-90, fresco, Tornabuoni Chapel, church of Santa Maria Novella, Florence. 
Bartolomeo in the cathedral of Volterra ${ }^{31}$ and Giovanni Bellini in the Galleria dell'Accademia in Venice. ${ }^{32}$

In the Flemish painting some Annunciations with lilies are not less interesting, such as those of Melchior Broederlam in the Dijon Altarpiece, ${ }^{33}$ Jan van Eyck in the National Gallery of Art in Washington DC, ${ }^{34}$ Robert Campin (Master of Flemalle) in the Mérode Altarpiece, ${ }^{35}$ Rogier van der Weyden in his panel in the Musée du Louvre, ${ }^{36}$ Petrus Christus in his two versions of Bruges ${ }^{37}$ and New York, ${ }^{38}$ Hans Memling in his two paintings at the New York's Metropolitan Museum of Art, ${ }^{39}$ and Gerard David in the same museum. ${ }^{40}$ In Germany the Annunciations with lilies of the Master of Cologne in Walraf-Richartz Museum ${ }^{41}$ and the Master of Aix in the Magdalene church of Aix-en-Provence are also prominent. ${ }^{42}$

In the field of Spanish Gothic painting there are also many Annunciations with stem of lilies: among the twenty three survivors we have recorded here, we will discuss in this paper, as mere examples, the following twelve: Arnau Bassa in the Walters Art Gallery in Baltimore, Pere Serra in the altarpiece of Abellà de la Conca, Lluís Borrassà in the San Gabriel Altarpiece in the Barcelona Cathedral, Pere Vall in the Holy Spirit Altarpiece of Cardona, Jaume Huguet in Cervera de la Cañada, Jaume Serra in the altarpiece of the

\footnotetext{
${ }^{31}$ Fra BARtolomeo, The Annunciation, 1497, panel, 176 x $170 \mathrm{~cm}$. Volterra Cathedral.

${ }^{32}$ Giovanni Bellini, The Annunciation, c. 1500, oil on canvas, 224 x $105 \mathrm{~cm}$ (each part), Gallerie dell'Accademia, Venice.

33 Melchior Broederlam, The Annunciation, left panel of the Dijon Altarpiece, 13931398, tempera on wood, 167 x $249 \mathrm{~cm}$ (the whole). Musée des Beaux-Arts, Dijon.

${ }^{34}$ JAN VAN EYCK, The Annunciation, c. 1435, oil transferred from wood to canvas, 93 x 37 $\mathrm{cm}$. National Gallery of Art, Washington D.C.
}

${ }^{35}$ Robert CAMPIn (MASTER OF FlÉMALLE), The Annunciation, central panel of the Mérode Altarpiece, c. 1427, oil on wood, 64,1 x 117,8 cm (the whole). Metropolitan Museum of Art, New York.

${ }^{36}$ ROGIER VAN DER WeYDEN, The Annunciation, c. 1440, oil on wood, 86 x $92 \mathrm{~cm}$, central panel of the Triptych of The Annunciation, c. 1440, 87 x 36,5 cm (each wing), Musée du Louvre, Paris,

37 Petrus Christus, The Annunciation, 1452, oil on wood, 85,5 x 54,8 cm. Groeningemuseum, Bruges (Belgium).

${ }^{38}$ Petrus Christus (attributed), The Annunciation, c. 1450, oil on wood. Metropolitan Museum of Art, New York ( $n^{\circ}$ inv: 32.100.35).

39 Hans Memling, The Annunciation, c. 1465-75, oil on wood, 186,1 x 114,9 cm. Metropolitan Museum of Art, New York ( $\mathrm{n}^{\circ}$ inv: 17.190.7); HANS MEMLING, The Annunciation, c. $1480-89$, oil on wood transferred to canvas, 76,5 x 54,6 cm. Metropolitan Museum of Art, New York ( $\mathrm{n}^{\mathrm{o}}$ inv: 1975.1.113).

${ }^{40}$ GERARD DAVID, The Annunciation, 1506, oil on wood, aprox. 79 x $125 \mathrm{~cm}$ (the whole of both panels). Metropolitan Museum of Art, New York ( $\mathrm{n}^{\mathrm{o}}$ inv: 50.145.9ab).

${ }^{41}$ Master of Cologne, The Annunciation, c. 1320. Walraf-Richartz Museum, Colonia.

${ }^{42}$ MASTER OF AIX (MAîTRE D’AIX), Triptych of The Annunciation, c. 1442-1445, church of St. Marie-Magdalène, Aix-en-Provence. 
Convent of the Holy Sepulcher in Zaragoza, Bernat Martorell in the Morgan Collection of Montreal, Jaume Ferrer II in the altarpiece of Verdú, Juan de Burgos in the painting at the Fogg Art Museum, Nicolás Francés in the La Bañeza Altarpiece, Pedro de Córdoba in the Cordoba Cathedral and Pedro Berruguete in the Cartuja de Miraflores.
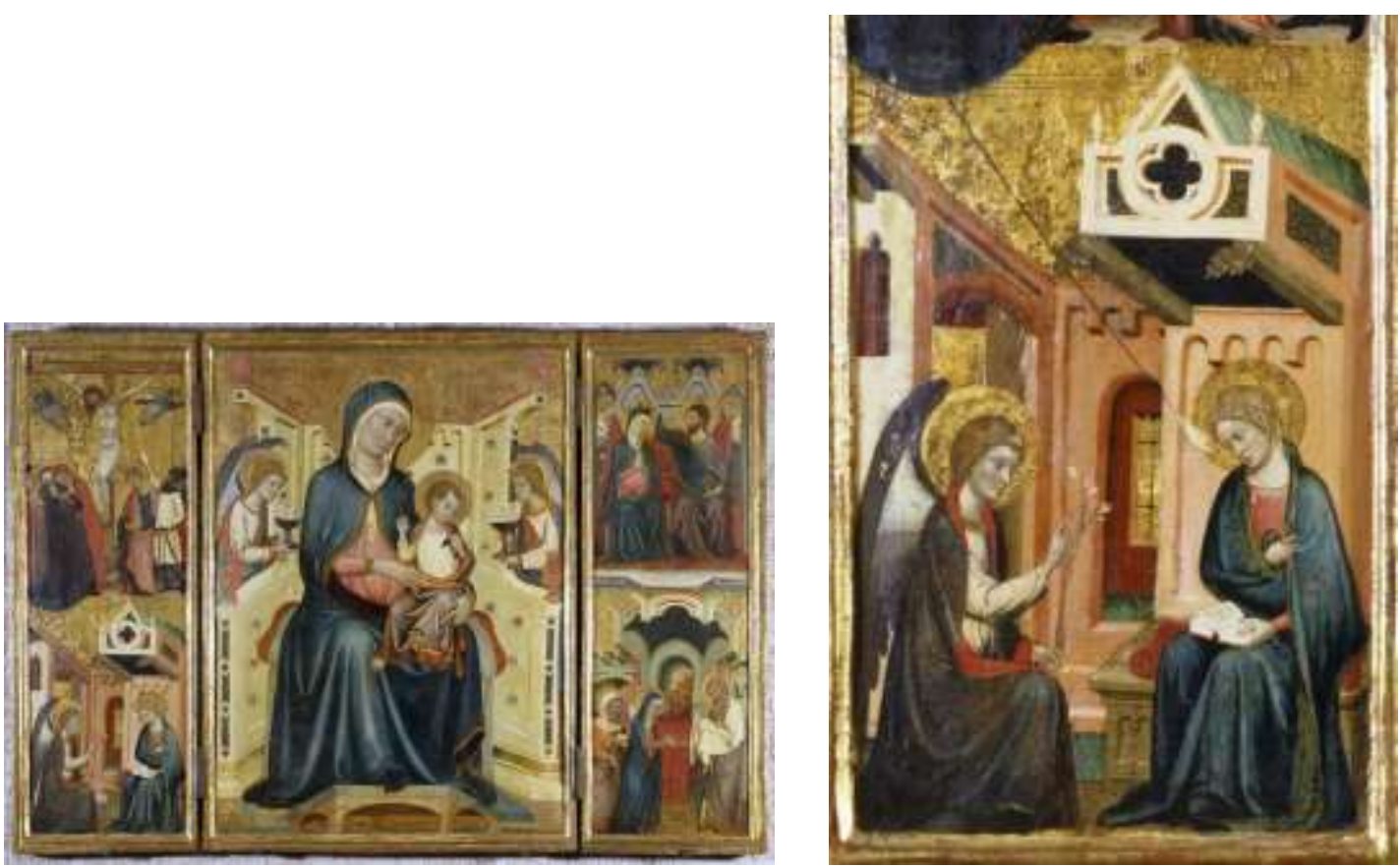

Fig. 1a. Arnau Bassa, Triptych of the Virgin and Child with Annunciation and Crucifixion, Walters Art Gallery, Baltimore.

Fig. 1b. Arnau Bassa, The Annunciation, detail of the left wing of the preceeding triptych.

Among the Spanish Gothic Annunciations selected for the current paper, the one painted by Arnau Bassa (doc. 1345-1349) ${ }^{43}$ in his Triptych of Virgin and Child with Annunciation and Crucifixion, today in the Walters Art Gallery in Baltimore (Figs. 1a and $1 \mathrm{~b}$ ) ${ }^{44}$ is the only one that represents the angel Gabriel carrying in his left hand the bouquet of lilies, while all the other works here chosen represent it within a vase or jug next to the Virgin. As in some of the twelve paintings under study, Gabriel lifts here his right hand toward the Virgin, in clear gesture of conveying the heavenly message and showing her election as Mother of God. Such circumstance -the newly inaugurated divine motherhood of Mary, in simultaneous parallelism with the God the Son's conception/incarnation in her womb - is here symbolized by the celestial lightning that, bringing in its trail the Holy Spirit in the form of a dove, drops obliquely from the left up to "penetrate" in the demure Virgin through her ear, a clear reference to the traditional thesis of the conceptio per aurem.

\footnotetext{
${ }^{43}$ For a relatively documented biography of Arnau Bassa, see Josep GUDIOL and Santiago Alcolea i Blanch, Pintura gótica catalana, Barcelona, Ediciones Polígrafa, 1986, p. 4546.

${ }^{44}$ ARNAU BASSA, The Annunciation, panel of the Triptych of the Virgin and Child with Annunciation and Crucifixion, $127 \times 185 \mathrm{~cm}$ (the whole). Walters Art Gallery, Baltimore (inv. No 37.468), Repr. en GUdiol, AlCOLEA 1986: 297, fig. 201.
} 
José María SAlVAdor GonZÁLEZ, Flos de radice Iesse. A hermeneutic approach to the theme of the lily in Spanish Gothic painting of The Annunciation from patristic and theological sources

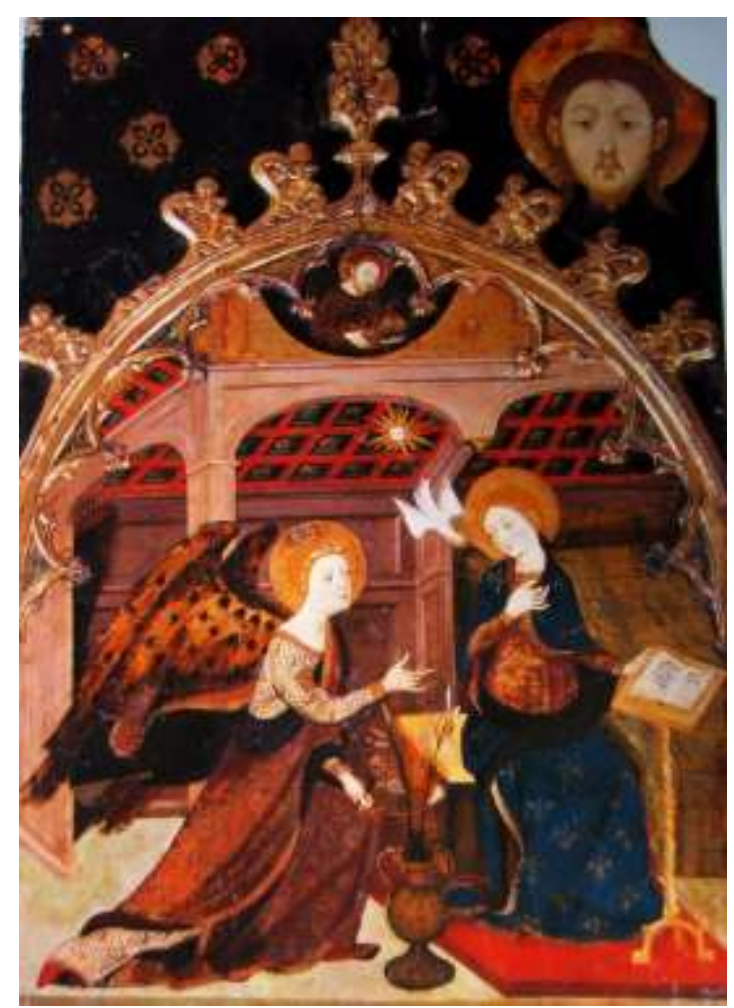

Fig. 2. Jaume Serra, The Annunciation, of the Altarpiece of the Resurrection of the Convent of the Holy Sepulcher, Zaragoza, c. 1361. Museo Provincial de Bellas Artes, Zaragoza.

Jaume Serra (docum. 1423-1446) ${ }^{45}$ adds several significant elements to his Annunciation at the top of the Altarpiece of the Resurrection of the Convent of the Holy Sepulcher in Zaragoza, ${ }^{46}$ c. 1361 (Fig. 2). ${ }^{47}$ The painter, in effect, besides the fact of representing the Holy Spirit like a dove, locates at the top of

45 For a brief biography of Jaume Serra, with some documented data, see GUDIOL, ALCOLEA 1986: 53-55.

${ }^{46}$ JAUME SERRA, The Annunciation, compartment of the Altarpiece of the Resurrection of the Convent of the Holy Sepulcher, Zaragoza, c. 1361, tempera on wood, 156 x $108 \mathrm{~cm}$. Museo Provincial de Bellas Artes, Zaragoza. Repr. in Gudiol, Alcolea 1986: 307, fig. 242; and in LACARRA DUCAY, María del Carmen et al., La pintura gótica en la corona de Aragón (cat. exh.), Museo e Instituto Camón Aznar, Zaragoza, 1980, p. 75 (with analysis in p. 74).

${ }^{47}$ Interesting data are offered in the anonymous commentary of this work, inserted in the catalog of the exhibition aforementioned in the preceding note: "La tabla de la Anunciación que aquí se exhibe es una de las que integran el retablo que Fr. Martín de Alpartir, tesorero del arzobispo de Zaragoza, había encargado a Jaume Serra para colocarlo delante de su tumba en el Convento del Santo Sepulcro de la capital aragonesa. En su testamento, redactado el 24 de junio de 1361, un año antes de morir, el mencionado canónigo señalaba que ya había entregado en depósito 100 florines al pintor de Barcelona y ordenaba a sus albaceas pagasen el resto de los 200 florines de los bienes que dejaba; añadía que los gastos de traslado y colocación del retablo debían correr a cargo del pintor. Es este el único retablo documentado de Jaume Serra que se ha conservado y constituye una base sólida para el conocimiento de la personalidad artística del pintor, tanto más por el hecho de ser obra temprana, realizada sin duda cuando Francesc ya había muerto y cuando la intervención de Pere, recién completada su formación en el taller de Destorrents, no podía ser todavía muy importante." (LACARRA DUCAY et al. 1980: 74). 
the panel God the Father half-body, while depicting between both -God the Father and the Holy Spirit — God the Son in the form of a resplendent gold star with whitened face. Using such unusual layout of these three characters, the designer of the iconographic program of this painting seems to symbolize the Jesus' conception (the shape of the clear starry face resembles that of an embryo), ordered by God the Father (virtus Altissimi obumbrabit tibi) and made possible by the grace of the Holy Spirit (Spiritus Sanctus superveniet in te). As a symptomatic sign, the Virgin, who crosses with modesty her right arm on her chest trying to cover it, allows us to see between the edges of the open robe her swelling belly, in clear denotation of her pregnancy, a revealing sign of the already produced conception of Emmanuel. In an exceptional way, by comparison with the remaining paintings under analysis, Jaume Serra represents here the angel carrying in his left hand a bouquet of purplish flowers (symbol of humility?), while two stems of lilies emerge from a huge vase located in the foreground between the two actors of the episode. The major relevance of these lilies is so clear that it is very surprising to note that the anonymous analyst in this panel, in the catalog of an exhibition in Zaragoza that exhibited it, does not even mention in any time these lilies nor deals with unraveling its possible symbolism, while limiting himself only to the historical and stylistic analysis of the painting. ${ }^{48}$

An approach quite similar to the newly analyzed of his brother Jaume Serra is performed by Pere Serra (doc. 1357-1405) ${ }^{49}$ in his Annunciation in the summit of the altarpiece of the church of Abellà de la Conca, ante 1387, today in the Museo Diocesano de la Seu d'Urgell (Figs. 3a and 3b). ${ }^{50}$ With an almost identical morphology and distribution of the characters and the scenic

${ }^{48}$ In this regard the anonymous commentator says: "El concepto pictórico de Jaume Serra, claramente definido en esta tabla de la Anunciación, ilustra perfectamente la adaptación hecha por los seguidores de Arnau Bassa del estilo introducido por este. Las formas, tanto de las figuras como de los fondos, son básicamente las mismas, si bien se aprecia en ellas una significativa simplificación a causa de su reducción a unas fórmulas más o menos fijas. Vemos así cómo el modelado de caras y pliegues se hace más elemental, con una mayor intervención de la línea para delimitar los volúmenes, que tienden hacia una cierta geometrización. En las arquitecturas desaparece también la preocupación de crear un espacio que contenga a los personajes y se convierten en la mayoría de los casos en decorados de fondo. A pesar de todo, las pinturas de Jaume Serra tienen una indudable calidad como obras decorativas. La dulzura de sus personajes, especialmente perceptible aquí en la magnífica Santa Faz que aparece sobre el fondo del encuadramiento, les confiere un particular encanto que queda realzado por la suavidad de la gama cromática y la exquisita imitación que se hace de las telas brocadas mediante estarcido de un motivo ornamental sobre un fondo dorado." (LACARRA DUCAY et al. 1980: 74).

${ }^{49}$ For an extensive biography of Pere Serra, with numerous documented data, see GuDIOL, ALCOLEA 1986: 55-57.

${ }^{50}$ PERE SERRA, The Annunciation, panel of the Altarpiece of the Virgin, from the church of San Esteban de Abellà de la Conca (Pallars Jussà), ante 1387, tempera on wood, 216 x 155 $\mathrm{cm}$ (the whole). Museo Diocesano de La Seu d'Urgell (inv. $\mathrm{N}^{\circ}$ 131). Repr. in Gudiol, AlCOLEA 1986: 312, fig. 270; and in Josep BRACONS and Juan-Ramón Triadó, La pintura española. Románico, Gótico, Renacimiento, Barcelona, Carroggio, Col. Arte Carroggio, 2000, p. 112. 
elements, Pere Serra also locates on the cusp of the panel God the Father halfbody, while, sliding down in the lower end of the divine ray, the dove of the Holy Spirit is approaching the right ear of the modest Virgin. In a way even more explicit than that of his brother Jaume, Pere Serra puts in evidence here the pregnancy of Mary, who caresses with her left hand her swelling belly, as a sign of having already conceived miraculously to the Redeemer through the power of the divine Spirit.
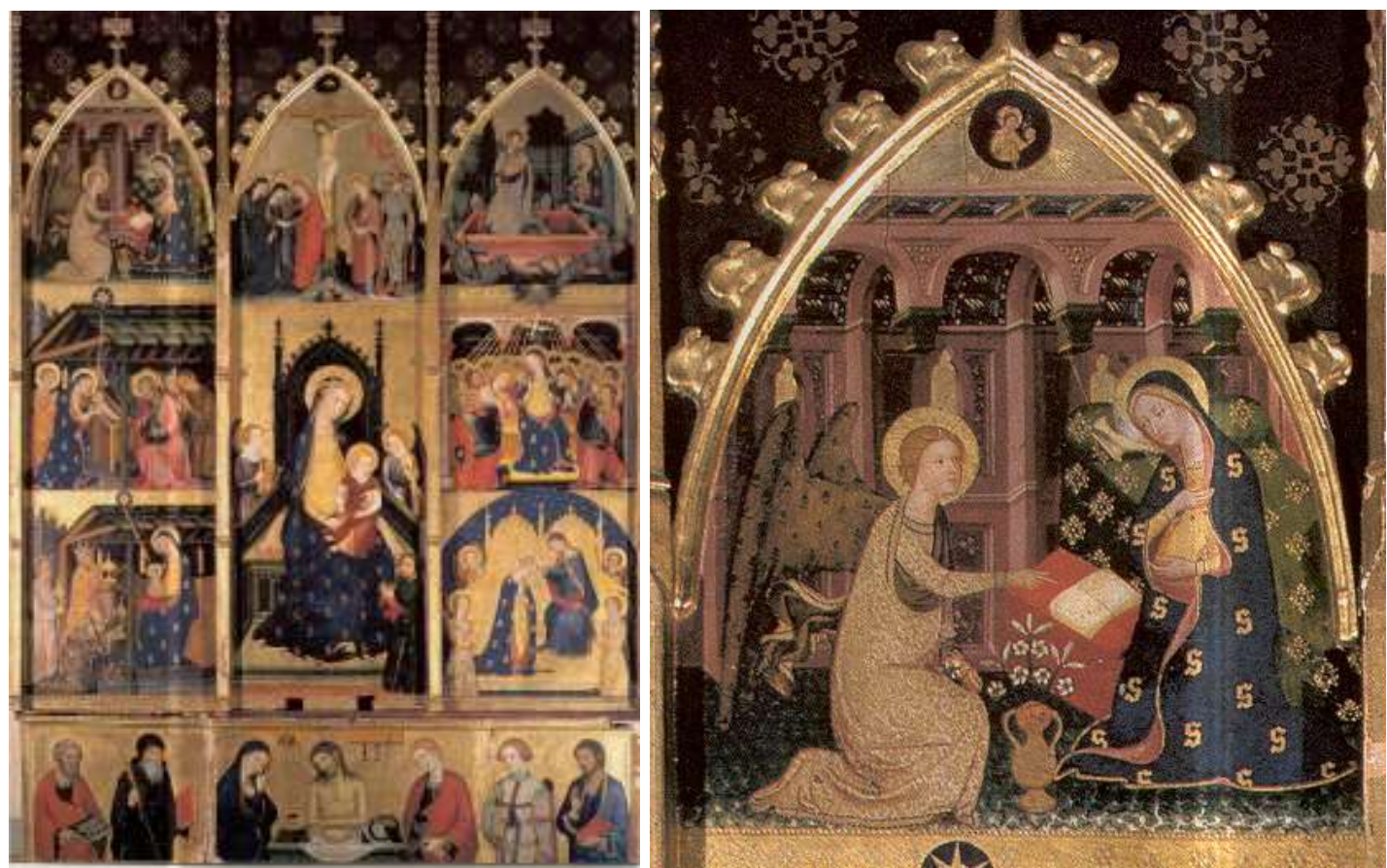

Fig. 3a. Pere Serra, Altarpiece of the Virgin, from the church of San Esteban de Abellà de la Conca (Pallars Jussà) (ante 1387). La Seu d'Urgell. Museu Diocesano. Image Bracons, Triadó 2000, 112. ${ }^{51}$ Fig. 3b. Pere Serra. The Annunciation, top of the left wing of the panel of the Altarpiece of the Virgin of Abella de la Conca. La Seu d'Urgell. Museu Diocesano. Image Bracons, Triadó 2000, 112.

By comparison with the previous three artists, Bernat Martorell (doc. 14271452), ${ }^{52}$ in his Annunciation of the Morgan Collection in Montreal (Fig. 4), ${ }^{53}$ raises two interesting developments: firstly, he locates God the Father in the upper left corner, outside of the maiden's enclosure; furthermore he represents the impregnating divine ray passing through a stained glass window, to signify that the Jesus' conception was verified in Mary's womb while respecting her virginal integrity, in accordance with the analogy of the beam of light that passes through a glass without breaking or staining it. At the same time, Martorell locates the dove of the Holy Spirit on the Virgin's head -to

${ }^{51}$ Bracons and Triadó reproduce in their book this altarpiece of Pere Serra in an inverted position, in the direction left/right.

52 A comprehensive, well-documented biography of Bernat Martorell can be found in GUDIOL, ALCOLEA 1986: 121-125.

${ }^{53}$ Bernat MARTOReLl, The Annunciation, $80 \times 50 \mathrm{~cm}$, panel of a possible altarpiece of the Virgin. Collection Morgan, Montreal. Repr. in Gudiol, ALCOLEA 1986: 389, fig. 653. 
José María SALVAdor GonZÁLEZ, Flos de radice Iesse. A hermeneutic approach to the theme of the lily in Spanish Gothic painting of The Annunciation from patristic and theological sources

symbolize the angel's announcement that "the Holy Spirit will come upon you and the power of the Most High will overshadow you"-, while placing in the background the stem of lilies in its vase, behind both characters, in such a position that the right hand of the angel seems to hold it, despite the fact that it stands upright in the vase.

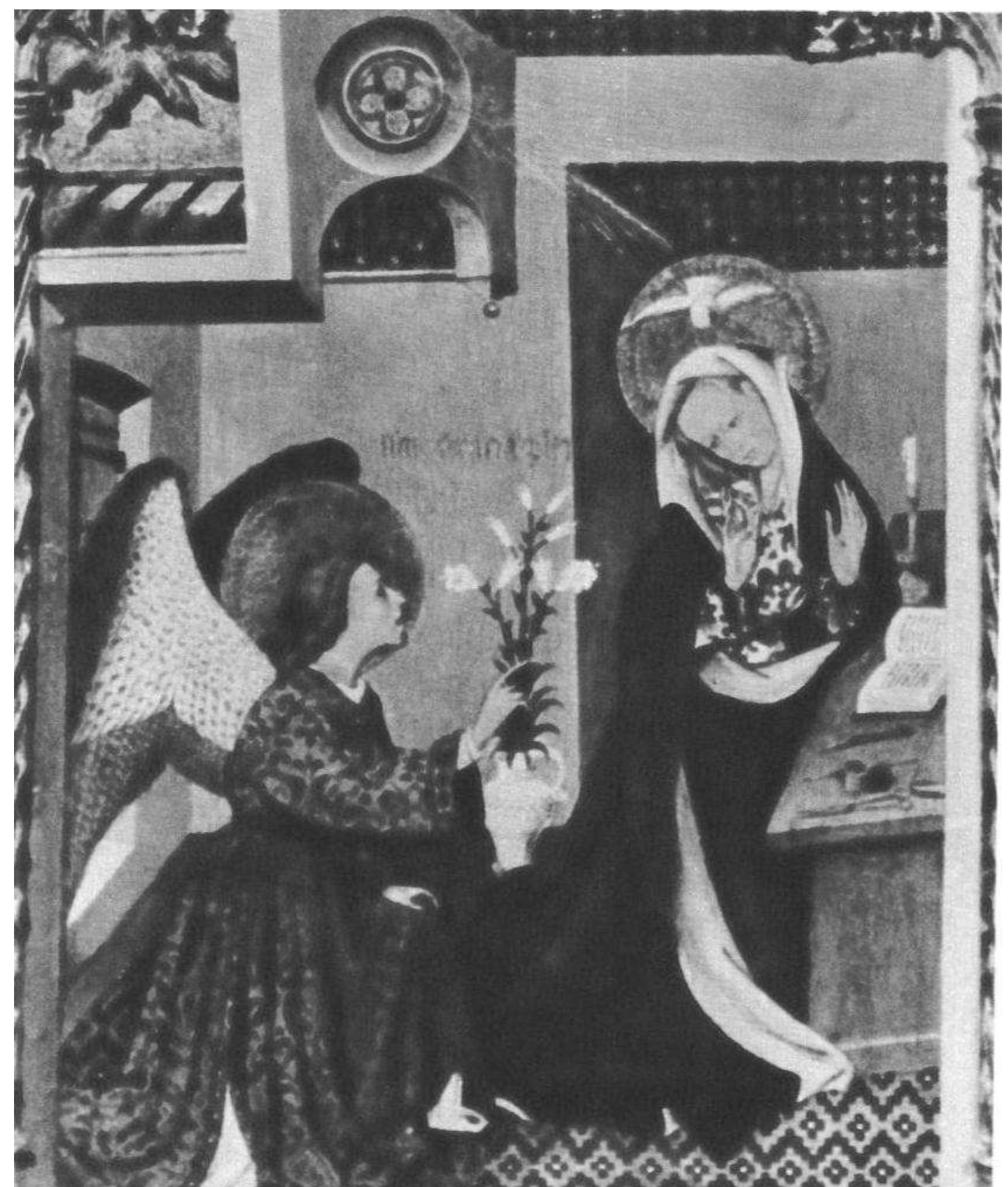

Fig. 4. Bernat Martorell, The Annunciation, Col. Morgan, Montreal. Image from Gudiol, Alcolea 1986: 389, fig. 653. 


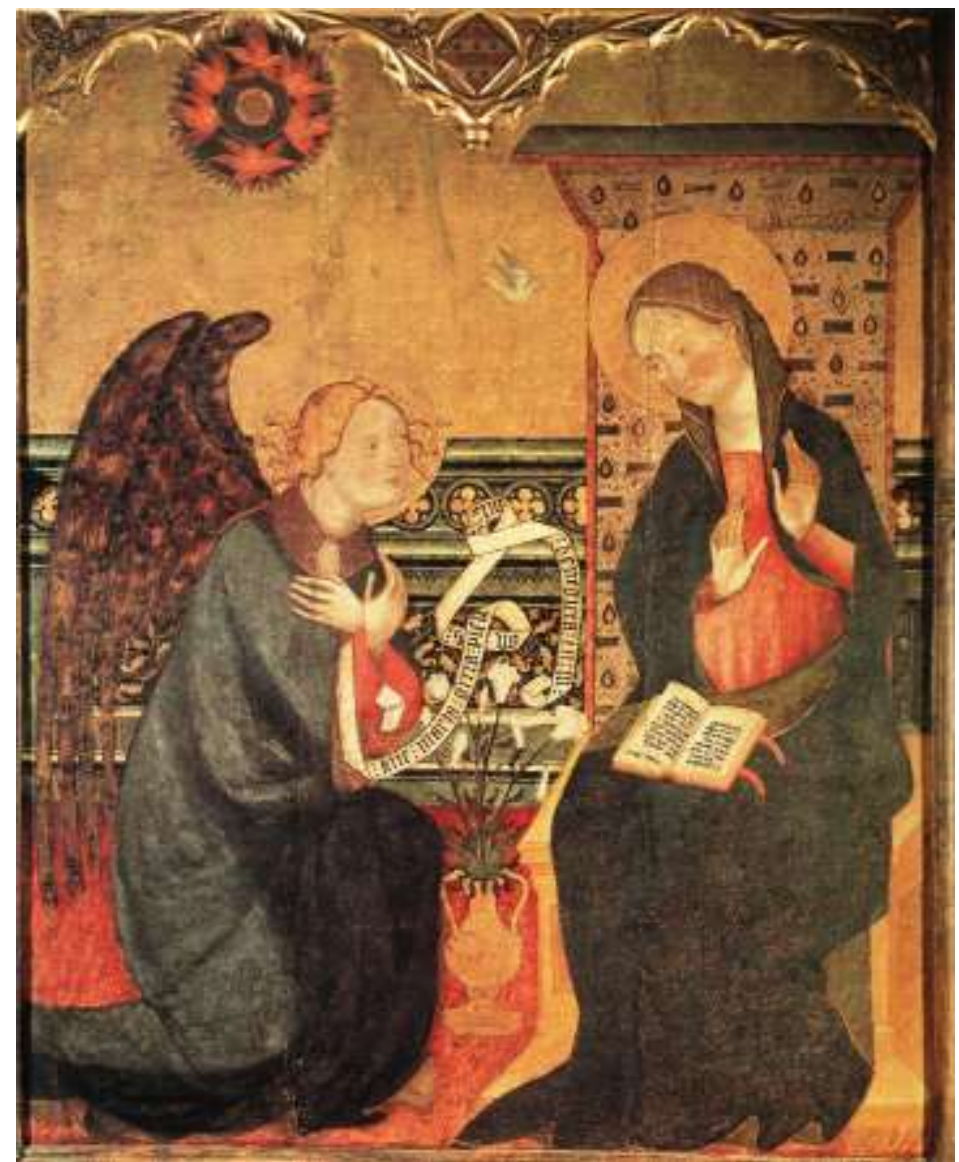

Fig. 5. Lluís Borrassà, The Annunciation, central panel of the St. Gabriel Altarpiece, Barcelona Cathedral. Image from Gudiol, Alcolea1986: 232, fig. 26.

The solution proposed by Lluís Borrassà (doc. 1380-1424) ${ }^{54}$ in his Annunciation of the altarpiece of San Gabriel in the Barcelona Cathedral ${ }^{55}$ $\left(\right.$ Fig. 5) ${ }^{56}$ is somewhat similar to that of Bernat Martorell. In this panel the power of the Most High is also represented by a circular round mandorla (like a window or stained glass) composed by six cherubim, which frame a sort of core or balloon (God the Father? God the Son?), from which comes off the Holy Spirit, in flight toward the Virgin's ear. However, Borrassà establishes in this painting several differences with regard to the other newly analyzed pictures: with the prayer book on her knees (in a position quite similar to that drawn by Arnau Bassa), Mary stretches out her hands with surprise, while the

${ }^{54}$ An extensive, well-documented biography of Lluís Borrassà is available in GUDIOL, ALCOLEA 1986: 75-80.

${ }^{55}$ Lluís BorRAssì, The Annunciation, central panel of the St. Gabriel Altarpiece, tempera on wood, 340 x $400 \mathrm{~cm}$ (the whole). Barcelona Cathedral. Repr. in GUDIOL, AlCOLEA 1986: 232, fig. 26; an p. 330, fig. 347.

${ }^{56}$ Josep Gudiol and Santiago Alcolea i Blanch report on this altar: "El retablo, instalado en la actualidad en una capilla de la girola, estuvo originalmente en una capilla del claustro de la Catedral de Barcelona. Ostenta el escudo de la familia Togores. En 1381, Guillermina, viuda de Francisco de Togores, fundó un beneficio dedicado a san Gabriel en la Catedral de Barcelona. En la visita pastoral de 1390 se menciona ya la existencia de este retablo." (GUDIOL, ALCOLEA 1986: 81, $\mathrm{n}^{\circ}$ 189). 
angel, in an attitude of respect, crosses his arms on his chest. The novelty more illustrative with respect to the preceding paintings lies, on the other hand, in the fact that Gabriel deploys here, holding it just with his right arm, a long and swaying scroll, whose legend exhibits the angel's congratulation: ave maria gr [a] tia plen [a] [...] benedicta tu in [...]. Such inscription involves, in fact -almost like identifying itself with them - the bulky stems of lilies that interconnect in their vase the heavenly herald and the maiden of Nazareth.

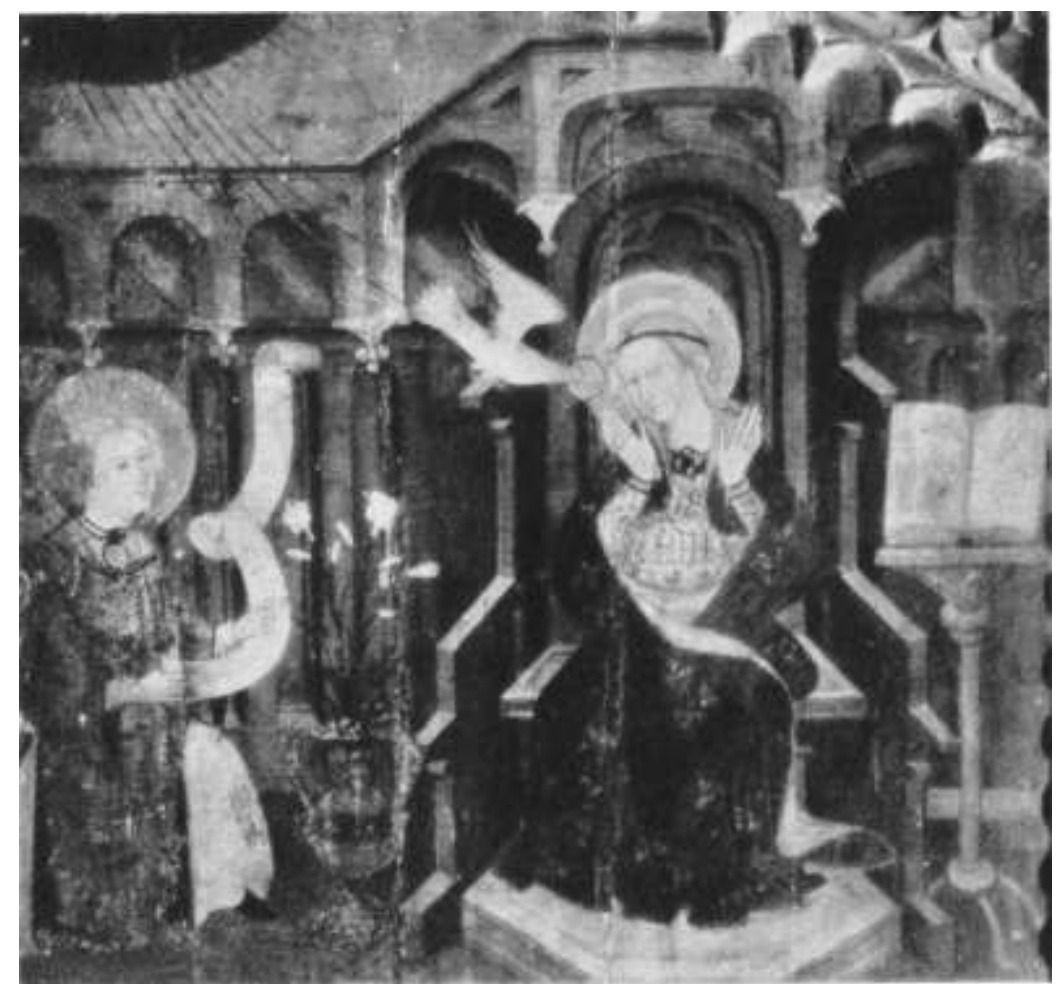

Fig. 6. Pere Vall, The Annunciation, panel of the Holy Spirit Altarpiece, parish church of San Miguel de Cardona (Bages). Image from Gudiol, Alcolea 1986: 359, fig. 477.

The proposal of Pere Vall (doc. 1405-1411) ${ }^{57}$ in the Annunciation of the Holy Spirit Altarpiece in the church of San Miguel de Cardona ${ }^{58}$ (Fig. 6$)^{59}$ is quite similar to the one above. Here the angel also unrolls his undulating scroll with the celestial message, before the fast flight of the divine Spirit toward the ear of the surprised Virgin, while the lush bunch of lilies that stands in the vase links physically and conceptually the kneeling messenger with the newly inaugurated Mother of Emmanuel.

\footnotetext{
${ }^{57}$ For a brief biographical sketch of Pere Vall, with a few documented data, see GUDIOL, ALCOLEA 1986: 97-98.

${ }^{58}$ Pere VAlL, The Annunciation, panel of the Holy Spirit Altarpiece, parish church of San Miguel de Cardona (Bages). Repr. in Gudiol, AlCOLEA 1986: 359, fig. 477.

${ }^{59}$ Gudiol and Alcolea i Blanch report on this altarpiece: "En la iglesia de San Miguel de Cardona hay una capilla dedicada al Espíritu Santo, que perteneció a la cofradía de idéntica advocación. Es interesante señalar que, el 2 de diciembre de 1410, Pere Vall firmó un reconocimiento de deuda a favor de dicha cofradía". (GUDIOL, ALCOLEA 1986: 98, n² 267).
} 


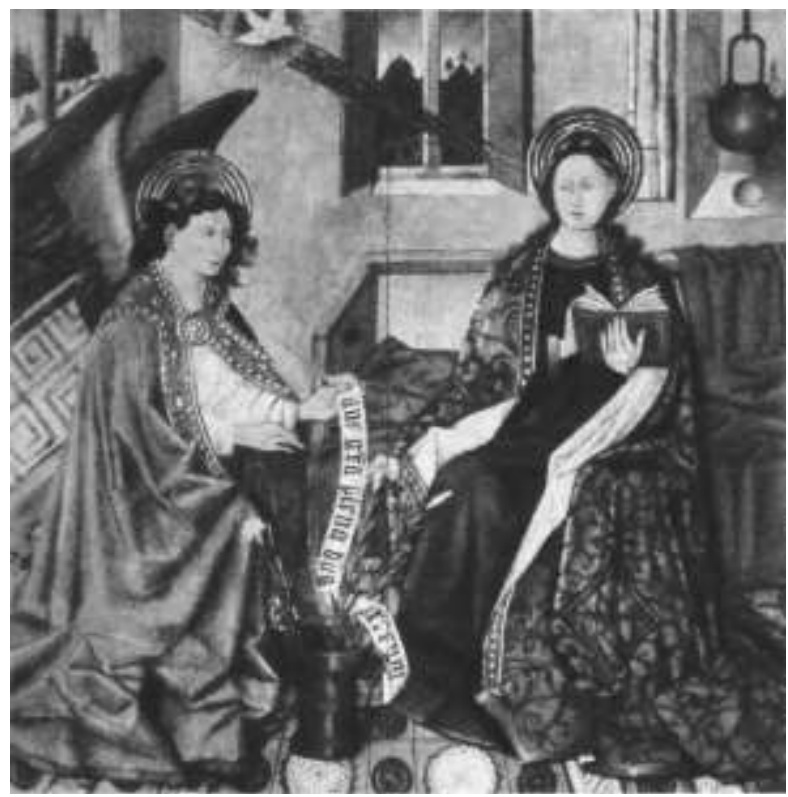

Fig. 7. Jaume Huguet, The Annunciation, c. 1435-1440, altarpiece in the church of Cervera de la Cañada (Instituto Amatller Barcelona. Imagen tomada de Gudiol, Alcolea 1986: 413, fig. 771.

Jaume Huguet (c. 1415-1419) ${ }^{60}$ includes in his Annunciation, c. 1435-1440, in the altarpiece of Cervera de la Cañada ${ }^{61}$ (Fig. 7$)^{62}$ some elements related to those of Pere Vall: the dove of the divine Spirit flies in oblique toward the Virgin's ear, who detaches her eyes from the prayer book and looks at the angel, while he is transmitting the message of the Almighty after the greeting ave gra[tia] plena D[omin] us tecum, inscribed on the scroll. The artist also blends here that laudatory band with the robust stems of lilies that arise from the jar.

${ }^{60}$ For a large biography of Jaume Huguet, with plenty of documented data, see GUDIOL, ALCOLEA 1986: 160-169.

61 Jaume Huguet, The Annunciation, c. 1435-1440, tempera on wood, 83 x $83 \mathrm{~cm}$, compartment of the main altarpiece in the church of Cervera de la Cañada (Instituto Amatller de Arte Hispánico, Barcelona). Repr. in LACARRA DUCAY et al. 1980: 117 (analysis in p. 116); and in. GUDIOL, ALCOLEA 1986: 413, fig. 771.

${ }^{62}$ In the analysis of this painting, the anonymous author states: "El retablo de Cervera de la Cañada sería la obra más temprana del grupo de pinturas aragonesas que pueden ser atribuidas a Huguet. La tabla de la Anunciación (...) es una de las que componen dicho retablo. En ella se aprecia ya la influencia del realismo flamenco, patente sobre todo en el intento de crear un marco ambiental absolutamente coherente, con una arquitectura trazada según unas normas muy elementales de perspectiva, amueblada detalladamente y con un fondo lejano de paisaje bajo el cielo gris azulado visible a través de dos ventanas. Idéntica filiación rigen los ampulosos pliegues quebrados de los ropajes. Las figuras de la Virgen y del arcángel San Gabriel están realizadas con sensibilidad; obsérvese la sugestiva expresión del celestial mensajero, de lánguida mirada y tenue sonrisa, o el sereno gesto de María que interrumpe la lectura del libro que hojea delicadamente para dirigir la vista al recién llegado." (LACARRA DUCAY et al. 1980: 116). The author of the analysis of this work in the aforementioned catalog is based on the comparison of stylistic features to justify the attribution of this table to Jaume Huguet (Ibid.: 116-117). In any case, one can greatly be surprised by the fact that this anonymous analyst says nothing about the symbolic significance of the remarkable stem of lilies, which does not even mention. 


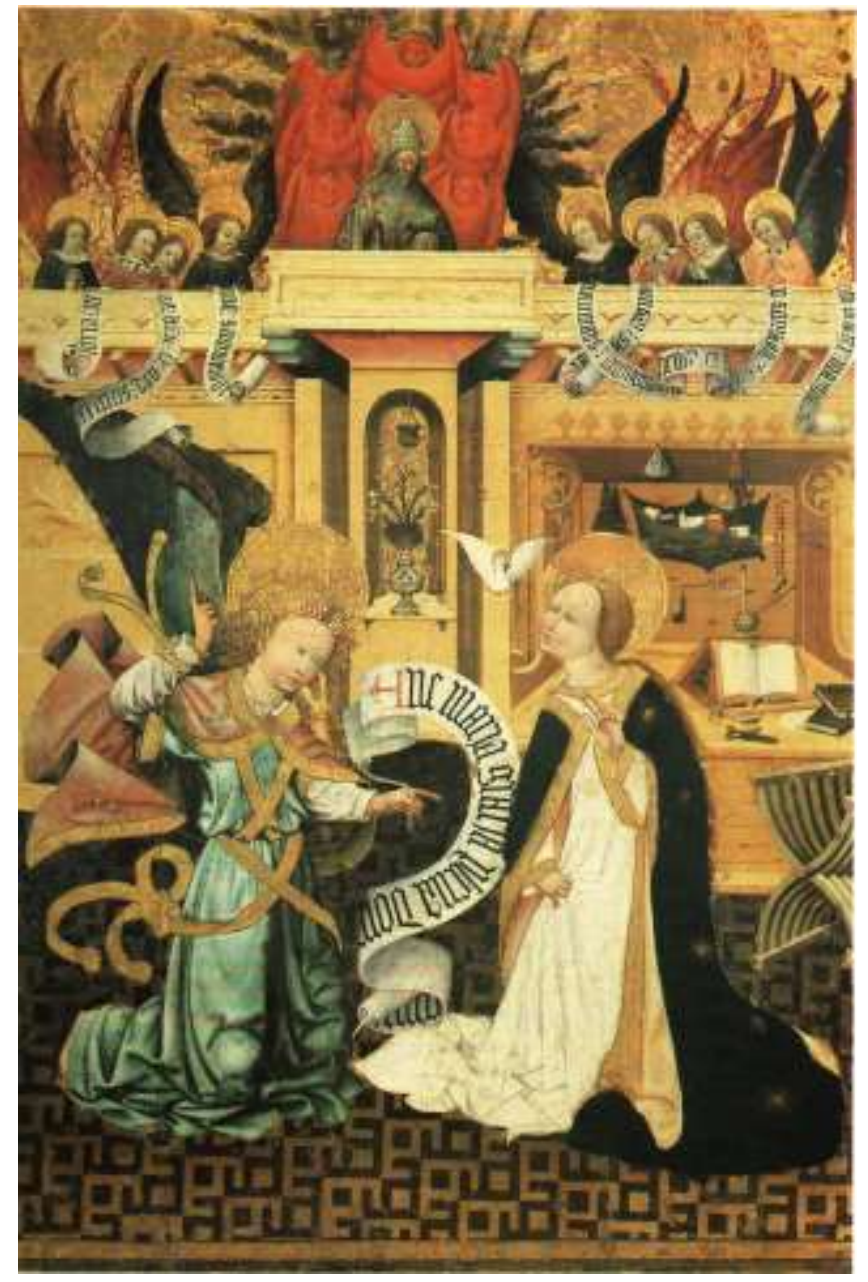

Fig. 8. Jaume Ferrer II, The Annunciation, panel of the altarpiece of the church of Santa María de Verdú, c. 1432-1434. Museo Episcopal, Vic. Image from Alcoy Pedrós 2007: 204, fig. 75.

From a complex and precious composition, filled with symbolic elements strikingly decorative, Jaume Ferrer II (doc. 1430-1457) ${ }^{63}$ offers in The Annunciation of the altarpiece of Verdú, in the Episcopal Museum of Vic (Fig. 9) ${ }^{64}$ some new significant content. Thus, the two central partners remain kneeling in the foreground, with Gabriel deploying between him and the Virgin - to better visualize the dialogue between both - a twisty scroll with the salutation Ave maria gratia plena Dom [inus tecum], whose elegant arabesque seven other phylacteries, sustained by vigilant angels on the ceiling of the

${ }^{63}$ For a biography of Jaume Ferrer II, with numerous documented data, see GuDIOL, ALCOLEA 1986: 141.

${ }^{64}$ JAUME FERRER II, The Annunciation, panel of the altarpiece of the church of Santa María de Verdú (Urgell), c. 1432-1434, aprox. 160 x 90 cm. Museo Episcopal, Vic. Inv. No 1.7721.783- Repr. in Gudiol, Alcolea 1986: 255, fig. 63; and in Rosa Alcoy Pedrós, "Talleres y dinámica de la pintura del gótico internacional en Cataluña", in María del Carmen LACARRA DUCAY (Coord.), La pintura gótica durante el siglo XV en tierras de Aragón y en otros territorios peninsulares, Zaragoza, Institución Fernando el Católico (CSIC), Col. Actas Arte, 2007, p. 413, fig. 771. Rosa Alcoy Pedrós (2007: 204) attributes this work to the "Workshop of Jaume Ferrer". 
architectural scenography, repeat in echo through successive melodic variations. Surrounded by a vibrant, red, round mandorla of Seraphim, God the Father, crowned with papal tiara and carrying in his right hand a sphere of the world, blesses the Virgin from a balcony or pulpit, that tops a kind of plane apse, whose niche -like a high "sanctuary"- is occupied by a bunch of leafy branches of lilies in a beautiful vase. It is very difficult not to notice the major symbolism, and the symbolic role, that the iconographic programmer of this painting has wanted to give to these stems of lilies, which dominate exactly the center of the symmetrical composition, within the impressive niche/tabernacle of the "apse", between the angel and the Virgin Mary, just under the majestic and protective figure of the Most High: evidently, these outstanding bouquets of lilies may not be a mere decorative accessory.

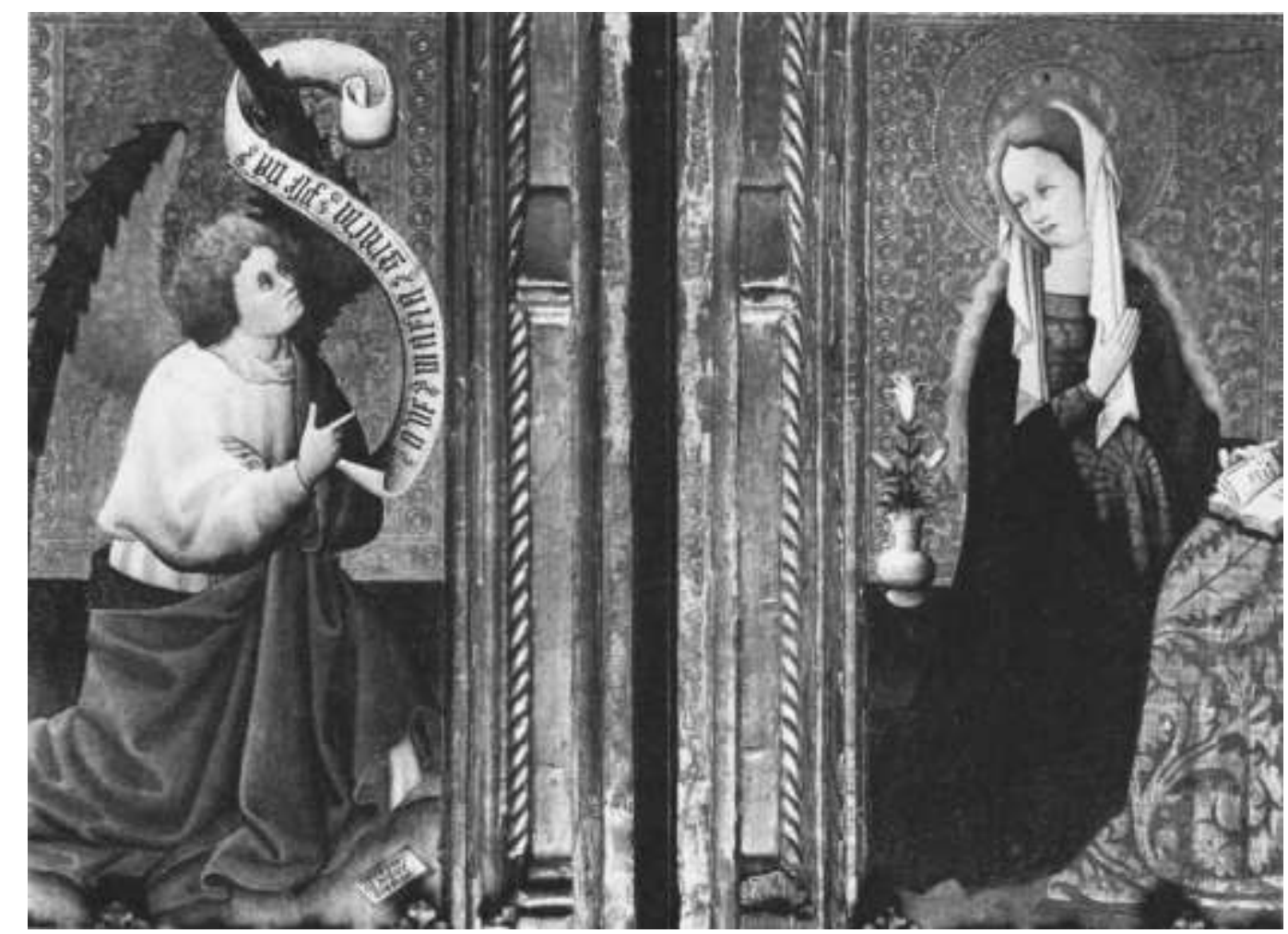

Fig. 9. Juan de Burgos, The Annunciation,. Fogg Art Museum, Cambridge, Mass. Image from Gudiol Ricart 1955: 231, fig. 202.

Juan de Burgos (s. XV) brings a few novelties in his Annunciation of the Fogg Art Museum in Cambridge (Mass.), a scene divided into two panels, each occupied by one or another protagonist (Fig. 9): ${ }^{65}$ to the already frequent scroll, twisting here in an open "S", with the angelic greeting ave maria gratia plena, the artist adds next to the kneeling Virgin an upright bouquet of lilies in a white jug, with a huge open lily in its top, while two other lilies are still in bud, in symmetrical order to both sides of the first.

\footnotetext{
${ }^{65}$ JuAn DE Burgos, The Annunciation, Fogg Art Museum, Harvard University, Cambridge, Mass. Repr. in José GUdiOl RICART, Pintura gótica, Madrid, Plus Ultra, 1955, p. 231, fig. 202.
} 


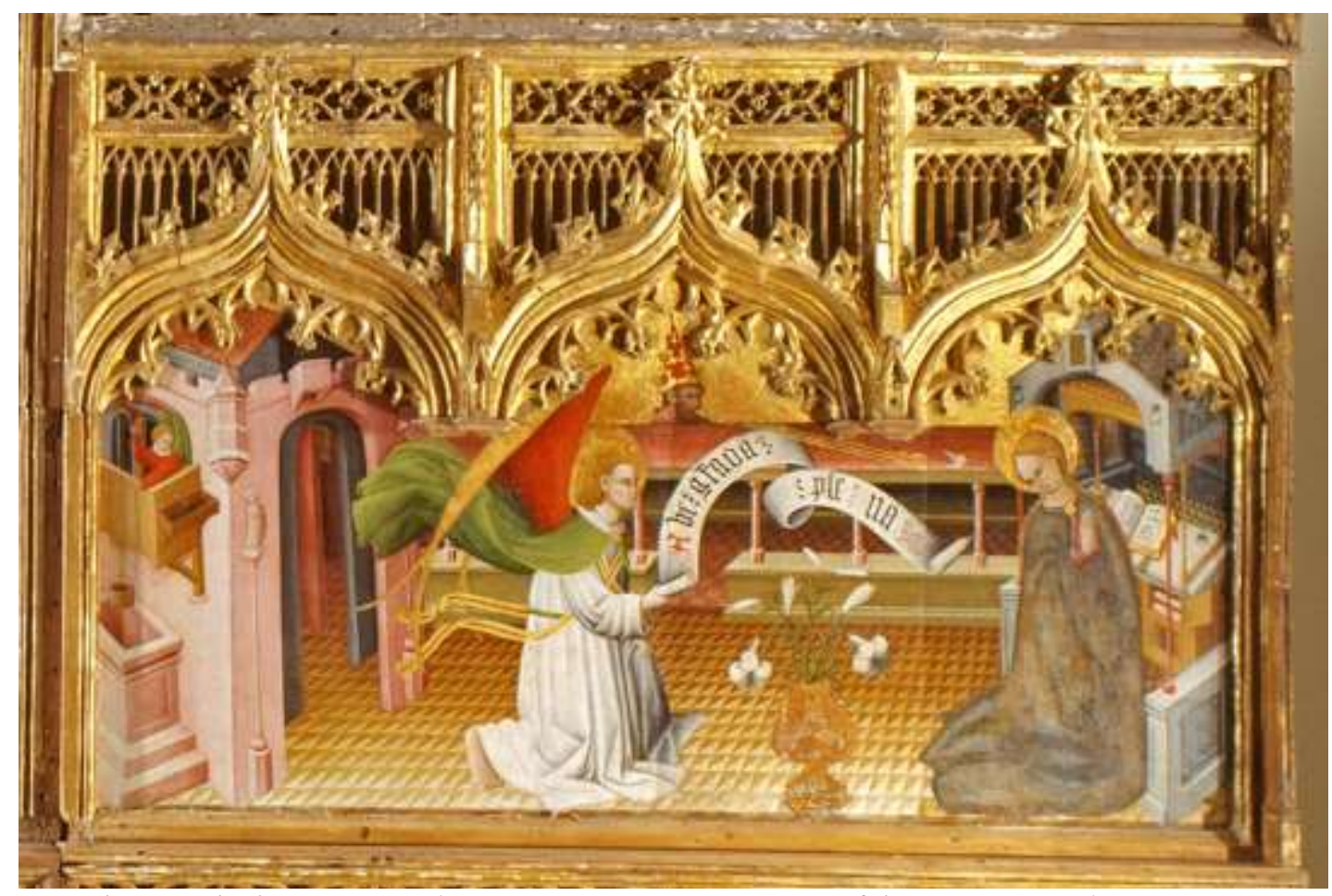

Fig. 10. Nicolás Francés, The Annunciation, compartment of the La Bañeza Altarpiece, c. 14451460, Museo del Prado, Madrid. Image from Bracons, Triadó 2000: 131.

The intellectual author that inspires Nicolás Francés in the La Bañeza Altarpiece, today in the Museo del Prado (Fig. 10), ${ }^{66}$ introduces a remarkable complexity in its composition and symbolic content. Just entered the house through the open door, the kneeling archangel unfolds his twisting eulogistic inscription toward the Virgin, who still remains in the prie-dieu in devout prayer in front of her book. It is interesting the detail that the sinuous scroll that connects both interlocutors is situated above the seven lilies of the vase, as if wanting to convey the idea that the exalted praise of the angel (ave gratia plena) constitutes the culmination/crowning and, at the same time, the reward for the theological attributes symbolized in the lilies. ${ }^{67}$ In the meantime, God the Father, girded with the papal triple crown, gives off from his mouth -as if it were a breath - the fertilizing beam that, carrying the Holy Spirit, penetrates through the Mary's ear. With so unusual emission of this bright halite -that recalls undoubtedly the breath with which the Creator breathed the life to Adam-, do the iconographic programmer of this painting would intend to symbolize also the Son of God's divine generation as a Verb/Verbum (because the halite/beam comes from the mouth of God the Father as a pronounced Word) and, at the same time, his human generation/incarnation in the Virgin's womb (as the beam penetrates through her ear)?

\footnotetext{
${ }^{66}$ NiCOLÁS FRANCÉS, The Annunciation, compartment of the La Bañeza Altarpiece, c. 14451460, oil and tempera on wood, $557 \times 558 \mathrm{~cm}$ (the whole). It comes from Esteva de las Delicias, La Bañeza (León). Museo del Prado (Inv. Nº P02545). Repr. in BRACONS, TRIADÓ 2000: 131 .

${ }^{67}$ In the central part of this paper we will expose those attributes symbolized in the stem of lilies.
} 


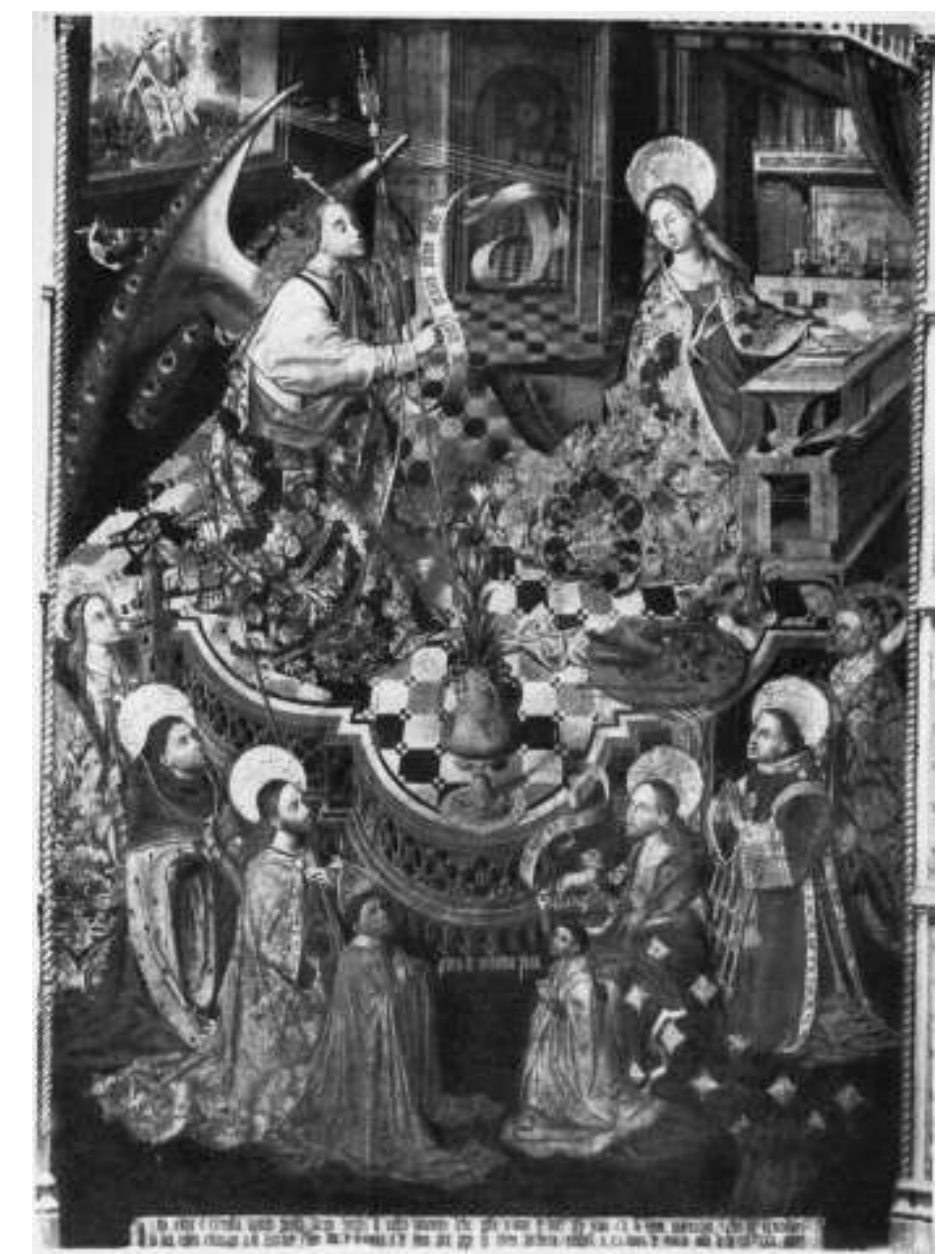

Fig. 11. Pedro de Córdoba, The Annunciation, cathedral of Cordoba Image from Gudiol Ricart 1955: 399, fig. 345.

The Annunciation of Pedro de Córdoba (second half of the fifteenth century) in the Cordoba Cathedral (Fig. 11) ${ }^{68}$ is even more complex and jumbled. Before the attentive gaze of six saints and two donors, the scene takes place without omitting any detail: the stylish archangel, exhibiting in his front a diadem and in his left hand a cane or baton of herald, flutters in the air his long scroll with the praise Ave maria gratia plena d[omin] us tec[um]. Sumptuously adorned with a brocade mantle, the surprised Virgin tours slightly her head before the supernatural visitor, still maintaining open with her left hand the pages of the book resting on a luxurious lectern. Girded with royal crown, lined with magnificent cope and carrying in his left hand a sphere with cross, God the Father releases with his blessing right hand the ray beam that, taking with it the divine Spirit like a dove, penetrates through the Virgin's ear to impregnate her. Finally, highlighted in the foreground in the very center of the space, on the prominence of the semicircular "proscenium" where the scene takes place, a lush stem of lilies expands freely after emerging from an unusual vase with multiple handles.

${ }^{68}$ Pedro DE CóRdobA, The Annunciation, cathedral of Cordoba. Repr. in Gudiol RICART, 1955: 399, fig. 345. 


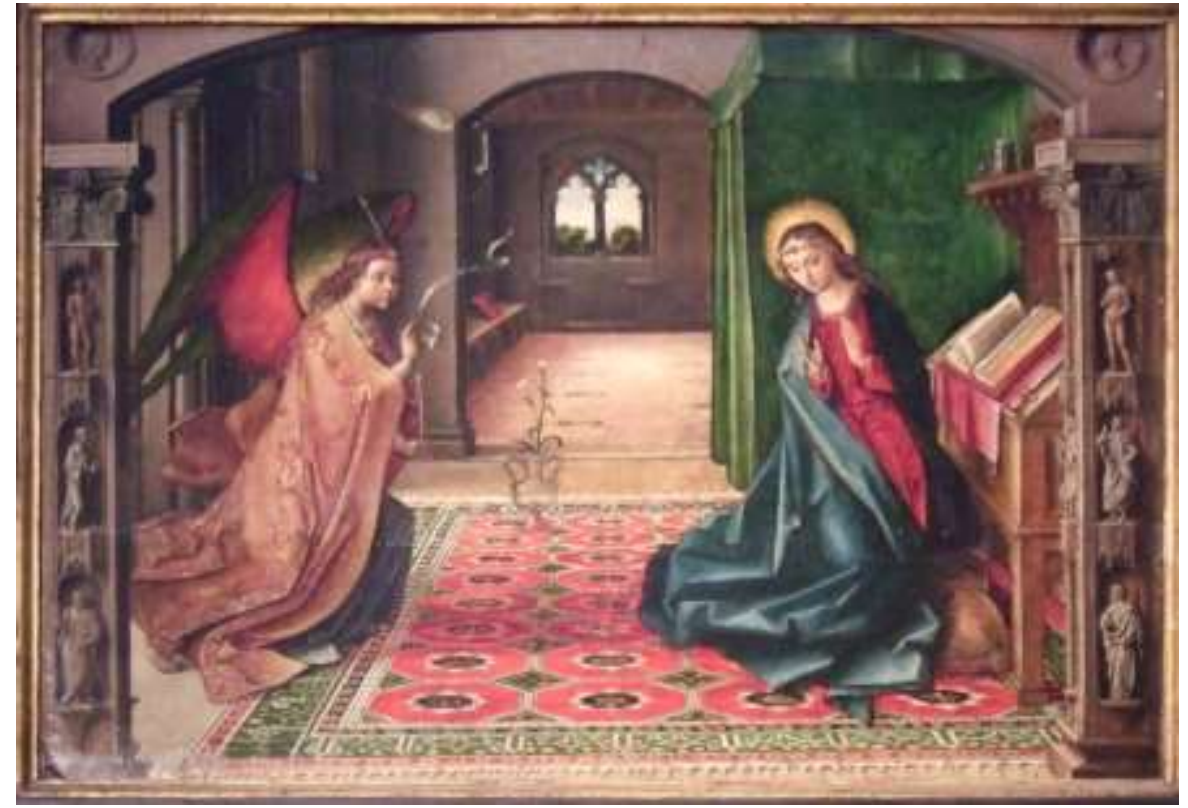

Fig. 12. Pedro Berruguete, The Annunciation, c. 1494-1504.

Cartuja de Miraflores, Burgos. Foto de Ecelan, tomada de Wikimedia Commons. ${ }^{69}$

Pedro Berruguete (c. 1450-1503) draws his Annunciation of the Cartuja de Miraflores in Burgos (Fig. 12) ${ }^{70}$ according to a clear and precise structure, full of eloquent symbolisms. Framed by a flattened arch whose jambs are occupied by the sculptural figures of Adam and Eve -to mark the essential link between the original sin and the need of the Savior's birth - and four prophets who predicted his advent, the scene of the angelic announcement is structured with perfect symmetry within the household of the humble maiden of Nazareth, which looks like a royal palace: this aspect may suggest that the modest "handmaid of the Lord" is at the same time the Queen of Heaven. In the Mary's carpeted alcove, in whose background to the right you can see the bed protected in its privacy by green curtains, the Virgin, still kneeling in her priedieu before the huge prayer book, turns with surprise toward the heavenly visitor. Covered with luxurious cope, adorned with a diadem with cross and carrying in his left hand a scepter, the ruddy archangel indicates with his right hand the announcement inscribed in the meandering phylactery, while the dove of the Holy Spirit slips on the divine ray projected toward the maiden's ear to impregnate her. The spacious compound, which with its bright mullioned window fills the large gap between the two protagonists serves almost as metaphorical niche where is exhibited -in slight runout - a stem with three lilies that stands in a transparent glass vase, which is perhaps a motif alluding to the beam of light that passes through the glass without breaking or staining it, as explicit rhetorical figure of the Mary's virginal divine motherhood.

http://commons.wikimedia.org/wiki/File:La_Anunciaci\%C3\%B3n_(Pedro_Berruguete).jpg (Last access: 15/09/2013).

${ }^{70}$ Pedro Berruguete, The Annunciation, c. 1494-1504. Cartuja de Miraflores, Burgos. 


\section{The meaning of the lily according to the experts in symbolism and iconography}

These Spanish gothic paintings of the Annunciation reveal clearly -as many other similar pictures in the European medieval art, mentioned above - the repetitive inclusion and the remarkable presence of the stem of lilies in such scenes. One can wonder therefore if the repeated prominence of such a peculiar flower does not hide any crucially important meanings.

The search for response to this question does not generate, unfortunately, satisfactory results when one reviews the literature specialized in symbols and iconographic subjects. In fact, all the specialists we consulted interpret the lily -without almost ever justifying their statements - in a generic and conventional sense, that has little to do with the true meanings that this flower assumes in the episode of the Annunciation, as we will try to show below.

Thus, for example, George Ferguson points in 1955 that the lily, the flower of the Virgin, represents the purity; ${ }^{71}$ and, even recognizing that it is often associated, especially, with the Annunciation, ${ }^{72}$ the author does not specify its real theological meaning in this so decisive event.

A biennium later the prestigious iconographer Louis Réau, in his influential work Iconographie de l'art chrétien, after pointing out that from the fourteenth century the flower of lily replaced the stick or scepter of the heavenly herald, thus becoming the more usual attribute of the announcing angel, ${ }^{73}$ expresses:

The floral emblem of the lily maintains in Christian iconography the same importance as the lotus in Buddhist art of India. Its immaculate snow whiteness, its asexual flowers, without stamens, allowed it to be elected as a symbol of purity, and more especially of the virginity of Mary, whom St. Bernard calls: inviolabile castitatis lilium. ${ }^{74}$

Reau completes his peculiar interpretation of the lily's symbolism in the scenes of the Annunciation in these terms:

\footnotetext{
71 "Lirio. Representa la pureza y es la flor de la Virgen. (...) Un lirio entre espinas representa la Inmaculada Concepción, señal de la pureza que conservó entre los pecados del mundo." (George Ferguson, Signos y símbolos en el arte cristiano, Buenos Aires, Emecé, 1956, p. 36).

72 "Se relaciona particularmente con los lirios un incidente de la vida de la Virgen: la Anunciación. En muchos cuadros que la representan, el arcángel Gabriel sostiene un lirio, o bien hay uno en un jarrón entre la Virgen y el ángel, por lo que esta flor es también atributo del arcángel Gabriel." (Ibid.).

${ }^{73}$ Louis RÉAU, Iconographie de l'art chrétien. Tome Second, Iconographie de la Biblie. II, Nouveau Testament, Paris, Presses Universitaires de France, 1957, p. 183.

74 "El emblema floral del lirio mantiene en la iconografía cristiana la misma importancia que el loto en el arte búdico de la India. Su blancura de nieve inmaculada, sus flores asexuadas, sin estambres, lo hicieron elegir como símbolo de la pureza, y más especialmente de la virginidad de María, a quien San Bernardo llama: inviolabile castitais lilium.” (Ibid.).
} 
The stem [of lily] often ends up in three flowers, which symbolize the triple virginity of Mary, before, during and after childbirth [...]. But in the scene of the Annunciation, the lily has only one open flower: the one which symbolizes virginity before conception; the other two are in cocoon. ${ }^{7}$

For almost the same dates (1958) Juan-Eduardo Cirlot insists on the topic that the lily, as an emblem of purity, is a Mary's symbol and attribute, particularly in the medieval iconography. ${ }^{76}$ Shortly after (1960) Gabriel Millet, after specifying that the western images of the Annunciation were often distinguished by a jug or vase with flowers, while the Byzantine counterparts prefer to include the source of life, ${ }^{77}$ argues that this vase -an ancient tradition in the western Annunciations - recalls a praise of St. Bernard to Mary. ${ }^{78}$

In another quite divergent interpretative line, Marie-Madeleine Davy asserts in 1969 that the lily means in the biblical tradition of the Song of Songs the choice of being loved, a privilege of the people of Israel among the nations, and of the Virgin Mary among the women of Israel. ${ }^{79}$ Five years later James Hall declared, without justifying his assertion, that the lily is the flower of the Virgin Mary, and that the Spanish painting associates it especially to the Immaculate Conception. ${ }^{80}$

75 "El tallo [del lirio] se termina con frecuencia en tres flores, que simbolizan la triple virginidad de María, antes, durante y después del parto [...]. Pero en la escena de la Anunciación, el lirio solo tiene una flor abierta: la que simboliza la virginidad antes de la concepción; las otras dos están en capullo." (Ibid.).

76 “Azucena. Emblema de la pureza, utilizado en la iconografía cristiana, especialmente en la medieval, como símbolo y atributo de la Virgen María. Con frecuencia aparece erguida en un vaso o jarrón, símbolo a su vez del principio femenino." (Juan-Eduardo CIRLOT, Diccionario de símbolos, Barcelona, Labor, 1969, p. 101). Although the quoted edition is of 1969, the first edition of this dictionary dates from 1958, when it was published in Barcelona by Luis Miracle editor with the title Diccionario de simbolos tradicionales).

77 "Le pot de fleurs appartient à l'Occident, la fontaine de vie, a Byzance." (Gabriel MiLLET, Recherches sur l'iconographie de l'Évangile aux XIVe, XVe et XVIe siècles d'après les monuments de Mistra, de la Macedoine et du Mont-Athos (Dessins de Sophie Millet), Paris, Éditions E. de Boccard, 1960, 2e édition, p. XL).

78 "Le motif [of the vase of flowers in The Annunciation] est ancient en Occident. Il rappelle une image gracieuse de saint Bernard: "o inviolabile castitatis lilium". Les Byzantins lisaient aussi dans les litanies del'Hymne Acathiste: Jaris tò ánthos tès afzarsías". (Gabriel MiLLET, op. cit., p. 91).

${ }^{79}$ Marie-Madeleine DAVY, "Lis", in Dictionnaire des symboles (sous la direction de Jean CHEVAliER, avec la collaboration d'Alain GHEERBRANT), Paris, Robert Laffont, 1969, p. 464. According to this author, the lily has another complementary meanings, since "It also means the abandonment to the will of God, providentially providing the need for the elect, who behave like the lily of the field, which, neither working nor spinning, are better dressed than Solomon. It also means the mystical abandonment to God's grace" (Ibid.)

80 "Lirio. Con mucha frecuencia, la flor de la Virgen, en vez de la azucena, en la primitiva pintura holandesa. Pueden verse las dos juntas en algunas ocasiones [...]. En la pintura española el lirio está asociado especialmente con la Inmaculada Concepción." (James HALL, 
And, while in 1989 Hans Biedermann declares that the lily, almost always present in the hand of the angel Gabriel at the Annunciation scene, "became in Christianity the symbol of pure, virginal love" ${ }^{81}$ the following year Federico Revilla states in his Diccionario de iconografia y simbologia that the lily is "a symbol of purity and innocence" and, since the Middle Ages, the maximum symbol of the Virgin Mary, but also, under the influence of the Gospel, is "a symbol of confidence in Providence and of peace, free from material concerns". 82

In recent times (2008) Udo Becker resumes through and through the conventional reading of this flower, claiming in apodictic way that, among other meanings, "The white lily [...] especially in Christian art, represents the purity, innocence, and virginity, mostly in relation to the Mary's figurations and, more particularly, the Annunciation by the archangel Gabriel". ${ }^{83}$

The analysis of these textbooks and dictionaries of symbols and iconography newly cited allows us to infer four decisive conclusions:

1) None of the authors of such texts -except the unfortunate case of Réau $^{84}$ — justifies with arguments the specific reasons why the lily symbolizes one or another of the alleged meanings proposed by them: purity, virginity, innocence, Virgin Mary, Immaculate Conception, etc. At last this turns the

Diccionario de temas y símbolos artísticos, Madrid, Alianza Editorial, Col. Alianza Diccionarios, 1987 (1974), p. 198).

${ }^{81}$ Hans Biedermann, Diccionario de símbolos, Barcelona, Paidós, 1993, p. 271. Although this is the Spanish translation of 1993, the original version in German of this dictionary, published in Munich, dates back to 1989.

82 "Lirio: Símbolo de la pureza y de la inocencia. También símbolo máximo desde la Edad Media en aplicación a la Virgen de aquella loa bíblica: Como lirio entre cardos es mi amada entre las doncellas (Cant., 2, 2). Su color blanco y la extrema suavidad de su tacto corroboran estas acepciones. Ya por influencia del Evangelio, el lirio fue símbolo de la confianza en la providencia y de la paz, libre de inquietudes materiales: Mirad los lirios del campo, cómo crecen y florecen; ellos no labran, ni tampoco hilan." (Mat., 6, 28)". (Federico Revilla, Diccionario de iconografía y simbología, Madrid, Cátedra. Col. Grandes temas, $8^{\text {a }}$ ed., 2012 (1990), p. 444). However, Revilla adds that other less limpid meanings of lily were postponed by this medieval symbolism: the author, in fact, points out that in ancient times the lily was associated with Venus and Satyrs, by the phallic shape of the pistil, and in China, for the same reason, this flower assumes an erotic sense. (Ibid., 444-445).

${ }^{83}$ Udo BECKER, Enciclopedia de los símbolos, Barcelona, Swing, 2008, p. 254.

${ }^{84}$ Louis RÉAU is the only one that seeks to justify his thesis that the lily is a symbol of purity and, above all, of the virginity of Mary, on the basis of the unacceptable arguments that the lilies are distinguished by "His immaculate whiteness of snow" and that they are "sexless flowers, without stamens" (sic)" (RÉAU 1957: 183). It is necessary to contradict such an illustrious expert in iconology that, while the white lilies are the most common and well known, among the more than one hundred species existing in the genre of lilies (of the family of liliaceous plants) there are many that are not white, but with gorgeous and varied colors, such as yellow, orange, red, pink, purple and other intermediate colors, often even mottled with points, stains or brush strokes of darker color. For the rest, all these species of lilies -by its condition of angiosperm plant - are fully sexual, with powerful stamens (male organ) around the pistil or gynoecium (female organ). 
"interpretations" of these specialists into mere gratuitous and unjustified speculations.

2) Furthermore, if the lily symbolizes the purity or virginity in general, this flower should appear in all -or at least in most images of the saint virgins, a circumstance (the presence of lily) that very rarely is manifested in them. The norm is that each one of the saint virgins (especially, if they are also martyrs) appears with her specific attribute: for example, St. Agnes with the lamb, St. Lucy with her eyes on a plate, St. Agatha carrying on a tray her breasts cut off, St. Barbara with a tower, St. Catherine of Alexandria with a broken sprocket and/or a sword, etc.

3) On the other hand, if the lily uniquely symbolizes the purity or the virginity of Mary, that flower should be present in all -or almost all - images of the ever virginal Mother of Jesus. However, while this flower is represented rarely in other scenes of Mary, including the subsequent Spanish images of the Immaculate Conception, ${ }^{85}$ the lily is, on the contrary, an element almost essential in the depictions of the Annunciation, mainly since the fourteenth century.

4) Finally, and above all, the fact that the lily is a major constant in almost all medieval Annunciations is justified because, while illustrating by the art the seminal episode of the Annunciation, the iconographic programmers of such images were inspired by an abundant, solid patristic and theological tradition that was able to see in the flower sprang from an only one stem ${ }^{86}$ some deep and essential meanings related to Mary and Christ, as we will try to explain later.

In summary, the stem of lilies in the medieval images of the Annunciation symbolizes at the same time Mary (to be more precise, her virginal divine motherhood) and Christ (in particular, the virginal conception/incarnation of the Son of God). Both symbolisms -Mariological and Christological- are exposed with reiterative emphasis by many Church Fathers and medieval theologians in countless exegesis on three eloquent Bible passages: Isaiah's prophecy on the flowering stem in the root of Jesse, the flowering of the Aaron's dray rod, and the allusion of the Song of Songs to the flower of the country and the lily of the valleys.

\footnotetext{
${ }^{85} \mathrm{We}$ are aware that the lily is also present in many images (especially Spanish) of the Immaculate Conception. However, it is necessary to clarify that in such representations of the Immaculate the lily assumes exactly -and based on the identical patristic and theological arguments that we will discuss later - the same Christological and Mariological meanings which that flower entails in the scenes of the Annunciation.

${ }^{86}$ Although there may be several of them in a single stalk, the flowers of the lily sprout at the top and around the top of a single vertical stem.
} 
The current paper will be focused on the exegesis on this first biblical text, while two other papers will analyze hermeneutically the last two aforementioned fragments of the Old Testament. ${ }^{87}$

\section{The flower in the stem of the Jesse's root, a symbolic prefiguration of the Mary's virginal divine motherhood and of the God the Son's incarnation}

On the basis of a comprehensive, consistent patristic and theological medieval tradition, the presence of the stem of lilies in the images of the Annunciation is explained with glaring evidence in the light of the Isaiah's prophecy when announcing that a flower will arise in the stem of the root of Jesse: Et egredietur virga de radice Iesse, et flos de radice eius ascendet. Et requiescet super eum spiritus Domini. ${ }^{88}$

This prediction of Isaiah is interpreted, in fact, with symptomatic insistence by the Church Fathers and medieval theologians as a clear and precise metaphor of the Mary's virginal divine motherhood, and, on the rebound, as a patent prefiguration of Christ himself, the Son of God incarnate in the Virgin Mary's womb. Without claiming to exhaust all the patristic and theological exegesis on this prophecy, the current paper will collect some illustrative examples of this issue.

Since the second century the apologist St. Justin Martyr (c. 100/114162/168) argues that the star emerged from Jacob and the flower sprouted from the Jesse's root, long-foreseen by Isaiah, is Jesus Christ, conceived and born, thanks to the power of God, of the womb of a virgin of the Jacob's lineage. ${ }^{89}$

At the beginning of the third century Tertullian (c. 155-C. 230) and St. Hippolytus Roman (170-235) adopt a similar position, by defining Mary as the stem emerged from the Jesse's root and Jesus as the fragrant flower germinated from this stem. The theologian and polemicist Tertullian, in effect, argues in a writing against the heretic Marcion that, if, by the full power of the Holy Spirit, Mary is the stem sprung out of the Jesse's root, the bloom will be Christ (Si enim plenitudo in illo Spiritus constitit, agnosco virgam de radice

\footnotetext{
${ }^{87}$ We have approached these two subjects in the papers "In virga Aaron Maria ostendebatur. Nueva interpretación del ramo de lirios en La Anunciación gótica española a la luz de fuentes patrísticas y teológicas", Anales de Historia del Arte, $\mathrm{n}^{\circ}$ 24, Universidad Complutense de Madrid, 2014, p. 37-60; and "Flos campi et lilium convalium. Tercera interpretación del lirio en la iconografía de La Anunciación en el Trecento italiano a la luz de fuentes patrísticas y teológicas", Eikón Imago, n ${ }^{\circ}$ 5, Universidad Complutense de Madrid, enero-junio 2014, p. 75-96.

${ }^{88}$ Is. 11, 1-2. En Biblia Sacra iuxta Vulgatam Clementinam, op. cit., p. 688.

89 "Atque Isaias alius propheta eadem verbis diversis praedicens sic fatur: Orietur stella ex Jacob et flos e radice Jesse ascendet, et in brachium ejus gentes sperabunt. Stella sane lucida exorta est, et flos ascendit e radice Jesse, hic Christus. Nam ex Virgine seminis Jacobi, qui Judae pater exstitit (Judam autem Judaeorum patrem esse ostendimus) per virtutem Dei genitus est.” (SAN Justino MÁRTIR, Apologia I Pro Christianis, 32. PG 6, 379).
} 
Iesse; flos eius meus erit Christus). ${ }^{90}$ In another passage of the same text, the author insists on the same interpretation, by confirming that the Jesus' future birth is manifested under the analogy of the flower sprout from the stem of the Jesse's root, which in turn means that Christ, the possessor of all the Spirit of God's substance, would be born of a virgin of the lineage of David, the Jesse's son. $^{91}$

In another fragment of the aforementioned polemic against Marcion, Tertullian abounds in his exegesis on the Isaiah's omen, when he points out that Jesus Christ is not only the flower that has arisen in the stem sprung up from the root of Jesse (a stem which identifies Mary), but is also its fruit. ${ }^{92}$ Hence the polemicist of Carthage infers that "The flower [...] is also the fruit: because through the blossom and from the flower all fruit is formed", in such a way that one can not, as the heretics pretend to do, deny "the flower to its fruit, the stem to its flower, and the root to its stem, in order to prevent the root claim for itself through the stem the ownership of what arises from the stem, i.e., the flower and the fruit". ${ }^{93}$

On the other hand, St. Hippolytus Roman (170-235), picking up on several occasions the aforementioned Isaiah's prognosis, says that, while the Jesse's root is the lineage of the ancestors as a root set on the ground, and the stem that arises from these is Mary, of the David's house and family, the flower that blossoms in the stem is Jesus Christ. ${ }^{94}$ In another oration, the same writer emphasizes that the Isaiah's flower is the same as the Jacob's seed, since it germinated first and flourished after. ${ }^{95}$ And in an exegetical comment to the

${ }^{90}$ Tertullianus c. 155-c. 230), Adversus Marcionem 3, 17. 3. PL 2, 344 C-345 A. In: Sergio Alvarez CAmpos (comp.), Corpus Marianum Patristicum, vol. I, Burgos, Aldecoa, 1970, p. 169.

91 "Prodibit virga de radice Jesse et flos de radice ascendet, requiescet super eum spiritus Domini [...] Christum enim in floris figura ostendit oriturum ex virga profecta de radice Jesse; id est virgine generis David filii Jesse, in quo Christo consistere haberet tota substantia spiritus." (TeRTUllianUs, Adversus Marcionem Liber V, 4. PL 2, 489).

92 "An quia ipse est flos de virga prophetae ex radice Iesse (radix autem Iesse genus David, virga ex radice Maria, flos ex virga, filius Mariae, qui dicitur Iesus Christus), ipse erit et fructus?" (TERTUllianus, Adversus Marcionem 21, 5-7. PL 2, 785 B-789 B. En Alvarez CAMPOS 1970: vol. I, 183).

93 "Flos enim fructus: quia per florem et ex flore omnis fructus eruditur. Quid ergo? Negant et fructui suum florem, et flori suam virgam, et virgae suam radicem, quominus radix suam sibi vindicet per virgam proprietatem eius quod ex virga est, floris et fructus?" (TERTULLIANUS, Ibid.: 182).

94 "Isaias enim loquitur: " Egredietur virga de radice Iesse et flos ex ea ascendet ». Radix itaque Iesse erat genus patrum ut radix in terra defixa, virga autem ex eis apparens erat Maria, quae ex domo erat ac patria Davidis. Flos denique in ipsa germinans erat Christus". (St. HipPolitus Roman, De benedictionibus patriarcharum, 1. In Alvarez CAmPOS 1970: vol. I, 61).

95 "Quod ita Isaias efert: "Egredietur virga de radice Iesse et flos ex ipsa ascendet." Quod Isaiae flos dictum est, id Iacob appellavit germen; primum namque germinavit, deinde floruit in mundo." (St. HiPPOlitus Roman, De Antichristo, 4. PG 10, 735 A. In Alvarez CAMPOS 1970: vol. I, 63). 
Genesis, St. Hippolytus concludes that this prophecy of Isaiah shows the human nature of the Son of God, Christ, by having been born of Mary's womb by the Holy Spirit's grace, like the flower which emerged in the stem sprung out of the Jesse's root. ${ }^{96}$

Eusebius of Caesarea (c. 275-339), to spell out the biblical quote "[He is] as a child before his presence, as one root in a thirsty land", asserts that the thirsty land symbolizes the Virgin Mary, which nobody has trampled on, while the root is the same that the prophet predicted: Egredietur virga de radice Iesse et flos de radice eius ascendet. ${ }^{97}$ With similar analogies St. Fortunatus of Aquileia (mid-fourth century) ratified a few decades later that the proverbial Isaiah's auspices must be understood in the sense that the stem is Mary, Mother of Jesus Christ, while the flower foreshadows Jesus himself, our Lord. ${ }^{98}$

The Roman-Spanish Gregory of Elvira (Gregorius Iliberitanus, 330-392), theologian, exegete and bishop of Elvira in Granada, further enriches the already solid hermeneutical consensus on the metaphor of the flower and stem, by elucidating similar rhetorical figure from the perspective of three Old Testament texts: two prophecies of Isaiah and Ezekiel and a verse of Genesis. The prelate of Granada, indeed, explains the Isaiah's prediction in the sense that -being Jesse the David's father, from whose root Mary was born, who is the "stem" from which the "flower" springs out - Christ is the "flower" arising out of that "stem", since he was born of the Virgin. ${ }^{99}$ In addition, the same holy of Elvira points out that the Ezekiel's prophecy, according to which "The days will pass and the stem will flower", means that the Virgin will bear the flower of the human race, Christ, so that the sentence of Genesis "My son, you sprout from the seed" was accomplished, because Mary, from whom the

\footnotetext{
96 "Demonstrans id quod Domini nostri erat secundum carnem, eum ex sancto scilicet Spiritu et Maria natum esse; dicit enim et alia in Scriptura: Egredietur virga de radice Iesse et flos sde radice ascendet." (ST. Hippolitus Roman, In Gen 49, 9. In Alvarez Campos 1970: vol. I, 64).

97 “'Quasi parvulus in conspectu eius, sicut radix in terra sitienti'... Per terram inviam Virginem subindicat, quem nemo adiit; per radicem vero eamdem ipsam de qua dicebatur: 'Egredietur virga de radice Iesse et flos de radice eius ascendet'." (EUSEBIUS OF CAESAREA, In Isaiam, 53, 1. PG 24, 456 D. In Alvarez CAMPOS 1970: vol. I, 36).

, "In virga quippe Mariam Genitricem Domini nostri Iesu Christi, in flore vero ipsum Dominum praefigurasse accipiendum est. Sicut Scriptura ait: 'Egredietur virga de radice

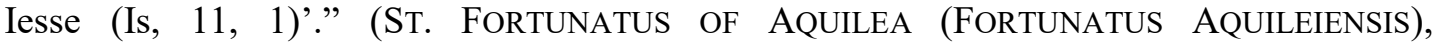
Commentarii in Evangelia I. In Sergio Alvarez CAMPoS, Corpus Marianum Patristicum, Burgos, Aldecoa, 1974, vol. III, p. 20).

99 “'Exiet virga de radice Iesse et flos de radice eius ascendet (Is 11, 1)'. Iesse iste pater fuit David, ex cuius radice, id est, origine Maria Virgo est nata, quam 'virga' Esaias appellat et 'flos' de virga, id est 'flos' Christum de virgine natum indicat." (GREGORY OF ELVIRA (GREgORIUS Illiberitanus, Tractatus Origenis 6, 36. In AlVAREZ CAMPOS 1974: vol. III, 72).
} 
flower, which is Christ, came, sprang from the germ of the Judah's seed. ${ }^{100}$

Perhaps for the same dates St. Ambrose of Milan (330-397) argues that the divine Spirit is the flower of the root from which, according to Isaiah, a stem of the Jesse's root, from which a flower would arise, would spring. ${ }^{101}$ Soon after, the author goes on to say the root is that of Jesse, patriarch of the Jews, the stem is Mary, and the Mary's flower is Christ, who had sprouted from a virginal womb to disseminate the good smell of faith across the globe, in accordance with the proclamation of the Song of Songs: "I am the flower of the field and the lily of the valleys". ${ }^{102}$

As St. Gregory of Elvira did before him, St. Ambrose also considers that the God the Son's incarnation is expressed in eloquent metaphor in the verse from Genesis "From the germ you did me arise"; this means, according to the bishop of Milan, that he who will germinate in the Virgin Mary's womb as a fruit of the earth, and, issued by the splendour of a new light, will emerge as a fragrant flower to redeem the world, in perfect agreement with the Isaiah's prophecy, announcing the outbreak of a stem in the Jesse's root, from which a flower would emerge. ${ }^{103}$ Hence St. Ambrose infers that, being the root the David's royal lineage, and being Mary the stem and Christ the flower, this stem of royal lineage (Mary), whose flower (Christ) eliminated the worldly filth, spread the smell of eternal life. ${ }^{104}$

St. Jerome (c. 340-420 340-420 340-420), in an exegesis on the foretelling of Isaiah, is totally opposed to the interpretation given by the Jews, according to which the stem and the flower in the Jesse's root is God himself, because the power of who reigns is shown in the stem, and his beauty in the flower; ${ }^{105}$

100 "Quod quidem et per Uzechielum prophetam sic dicitur: 'Ecce dies veniunt et virga florebit (Ez. 7, 10)'. Id est virgo pariet florem humani generis Christum. Et hoc est quod dicit: 'De germine filius meus ascendisti (Gen. 49, 9)'; quia ut dictum est, ex germine seminis Iudae prodibit Maria, unde flos Christus advenit." (Ibid.).

101 "Spiritus flos radicis est: ille, inquam, flos de quo bene est prophetatum: 'Exiet virga de radice Iesse et flos de radice eius ascendet (Is, 1, 11)'." (ST. AmBroSE, De Spiritu Sancto 2. PL 16, 750 C, o B.783 A. In Alvarez CAMPOS 1974: vol. III, 102).

102 "Radix Iesse patriarchae Iudaeorum, virga Maria, flos Mariae Christus, qui bonum odorem fidei toto sparsurus orbe virginali ex utero germinavit, sicut ipse dixit: 'Ego flos campi et lilium convallium (Cant. 2, 1)'." (Ibid.).

103 "Mirifice autem et incarnationem eius expressit, dicens: 'Ex germine mihi ascendisti (Gen. 49, 9)'; eo quod tamquam frutex terrae in alvo Virginis germinaverit, et ut flos boni odoris ad redemptionem mundi totius maternis visceribus splendore novae lucis emissus ascenderit, sicut Esaias dicit: 'Exiet virga ex radice Iessae et flos ex radice ascendet (Is. 11, 1)'." (St. Ambrose, De benedictionibus Patriarcharum 19. PL 14, 680 A, o 364 D. In ALVAREZ CAMPOS 1974: vol. III, 111).

104 "Radix familia Iudaeorum, virga Maria, flos Mariae Christus. Recte virga quae regalis est generis, de domo et patria David, cuius flos Christus est, qui factorem mundanae conluvionis abolevit, odorem vitae infudit aeternae." (SAT. AMBROSE, De benedictionibus Patriarcharum Liber Unus, 19. PL 14, 713).

105 "Et egredietur virga de radice Jesse, et flos de radice ejus ascendet (...). Virgam et florem de radice Jesse, ipsum Dominum Judaei interpretantur: quod scilicet in virga 
on the contrary, Christians interpret this stem in the Jesse's root as the Virgin Mary, who produced her unique flower and her fruit in a virginal way according to another augury of the same Isaiah: "Behold, a virgin shall conceive and bear a son"-, because the Spirit of God rests on that flower (Jesus), born suddenly of the trunk and the root of Jesse by means of the Virgin Mary. ${ }^{106}$

A similar opinion offers, for almost the same dates, Chromatius of Aquileia (c. 340-407/ 408), when he interprets the Isaiah's prophecy as a foreshadowing of that a virgin would give birth by the Holy Spirit's power, when he points out that with the stem at the Jesse's root is meant the Virgin Mary, of the David's tribe, since she is of the Jesse's lineage, a stem from which the flower of human nature came up in Christ incarnate. ${ }^{107}$

Eusebius of Alexandria ( $\uparrow$ c. 444) explains that same prophecy of Isaiah by identifying David with the Jesse's root, the Virgin Mary with the stem that flows from that, and Jesus Christ, the king begotten of the David's lineage, as the flower that arises from the stem. ${ }^{108}$ For almost the same dates, Hesiquius of Jerusalem († post 450) exposes similar thoughts, supplemented with the passage of the Song of Songs describing the Virgin Mary as "closed garden" and "sealed source", of whom the husband-Christ was born (Vocavit te hortum conclusum; et fontem signatum is qui ex te ortus est sponsus praedixit in Canticis). ${ }^{109}$ According to Hesiquius, in effect, to define Mary as a "closed garden" was justified by the fact that she had not the sickle nor the grape harvest of corruption, and because the flower of the Jesse's root, carefully

regnantis potentia, in flore pulchritudo monstretur." (ST. JEROME, Commentariorum in Isaiam Prophetam Liber IV, 11. PL 24, 144).

106 "Nos autem virga de radice Jesse, sanctam Mariam Virginem intelligamus, quae nullum habuit sibi fruticem cohaerentem; de qua et supra legimus: Ecce virgo concipiet et pariet filium (Isa. VII, 14). Et florem Dominum Salvatorem, qui dicit in Cantico Canticorum: Ego flos campi et lilium con vallium (Cant. II, 1). (...) Super hunc igitur florem, qui de trunco et de radice Jesse per Mariam Virginem repente consurget, requiescet spiritus Domini." (ST. JEROME, Commentariorum in Isaiam Prophetam Liber IV, 11. PL 24, 144).

107 "Alibi quoque per Esaiam virginem parituram sanctus Spiritus manifestat, cum dicit: Exiet virga de radice Iesse et flos de radice eius ascendet (Is. 11, 1). Virga de radice Iesse Virgo Maria significabatur, quae de stirpe Iesse per David originem ducit. De tribu enim David, ut evangelista vel apostolus manifestat, Virgo Maria fuit, de qua flos humanae carnis in Christo surrexit." (St. CROMACIUS OF AQUiLEA, Homilia in Mattheum 1, 6. In Alvarez CAMPOS 1974, vol. III: 175).

108 "Quod de genere Davidis nascituris sit, docet idem propheta clamans: 'Egredietur virga de radice Iesse et flos de radice eius ascendet'. Radicem vero vocat Davidem, ac virgam de radice egredientem Virginem Mariam, et florem de virga ascendentem Dominum nostrum Iesum Christum regem genitum." (EusebIUS OF ALEXANDRÍA, Sermo 10, de Christi nativitate. PG 86, 1, 367. In Sergio Alvarez CAMPOS (comp.), Corpus Marianum Patristicum, vol. IV/2, Burgos, Aldecoa, 1979, p. 221).

${ }^{109}$ Hesiquius of Jerusalem (Hesychius Hierosolimytanus), Sermo in Annuntiationem. PG 93, 1460 D-1468 A. In Sergio Alvarez CAMpos, Corpus Marianum Patristicum, vol. IV/1, Burgos, Aldecoa, 1976, p. 566. 
cultivated for her (the Virgin) by the pure and immaculate Holy Spirit, is manifested in her in full purity to mankind. ${ }^{110}$

Already in the fifth century the pope St. Leo the Great (c. 390-461) corroborates the conventional exegesis on the Isaiah's prediction, insisting that under the figure of the stem was predicted undoubtedly the Virgin Mary, who descending from the lineage of Jesse and David and impregnated by the Holy Spirit, produced in her maternal womb, although by means of a virginal birth, the flower of the human flesh of Jesus. ${ }^{111}$

Commenting on this same divination of Isaiah, Maximus of Turin (c. 380post 465$)^{112}$ points out that in the flower (Jesus) sprouted from the stem at the Jesse's root was not introduced any thorn of sin, for this flower did not rise from the spine, but from the stem, Mary, who was a "clean, subtle and virginal stem, that germinated Christ as a flower with the entire purity of her body."113

By those same decades St. Quodvultdeus (mid-fifth century) and Theodoret of Kyros ( $\uparrow$ c. 466) propose similar interpretations of the Isaiah's foresight. The first confirms that the stem represents the Virgin Mary, and the stem's flower Jesus Christ, because he is born ("as a small child, but as great king") of the Virgin as a flower is born of the stem, without need of any seed (semen). ${ }^{114}$ Theodoret of Kyros, in turn, corroborates that the words of Isaiah foreshadowed what would become the supernatural engendering of Emmanuel (Jesus) in the womb of a virgin, and showed his conception by the Holy Spirit, which set up in the uterus of a virgin the Word of God's temple, giving it a form of a servant

\footnotetext{
110 "Hortum conclusum, ob id quod falx corruptionis aut vindemia te non attingit; florem autem qui ex radici Iesse hominum generi pure exhibetur, excultus tibi a puro et intemerato Spiritu." (Ibid.).

111 "Hinc idem Dominus per Esaiam (...): 'Exiet virga de radice Iesse et flos de radice eius ascendet (Is. 11, 11).' In qua virga non dubie beata Maria Virgo praedicta est, quae de Iesse ac David stirpe progenita et Sancto Spiritu fecundata, florem carnis humanae, utero quidem materno, sed partu est enixa virgineo..." (ST. LEO THE GREAT, Tractatus 24, 1. PL 54, 203 C-206 A. In Sergio Alvarez Campos (comp.), Corpus Marianum Patristicum, vol. VI, Burgos, Aldecoa, 1981, p. 112).
}

112 Dates taken from Encyclopedia Cattolica in its online version http://ec.aciprensa.com/m/maximoturin.htm (Last access 12/11/2013).

113 "Nec enim erat in illo spina peccati, quae verteretur in florem; ipse enim erat flos natus non de spina sed de virga, sicut ait propheta: Exibit virga de radice Iesse et flos de radice ascendet (Isai. XI, 1): virga enim erat Maria, nitida, subtilis, et virgo, quae Christum velut florem integritate sui corporis germinavit." (ST. MAXIMUS OF TURÍN (MAXIMUS TAURINENSIS EPISCOPUS), Homilia XXXIX. PL 57, 310).

114 “4. Et alio in loco: 'Exiet virga de radice Iesse, et flos de radice eius ascendet (Is. 11, 1)': virga significans Virginem Mariam, et flore virgae filium virginis Dominum nostrum Iesum Christum. (...) 6. Nascitur Christus ex virgine sicut flos ex virga, sine ullo composito semine: nascitur infans parvus, rex magnus... (ST. QuOdvultDeus, De Symbolo II, 4 y 6, 228. In AlVAREZ CAMPOS 1981: vol. VI, p. 51). 
(human nature), to which the divine Word, after taking it in the very moment of his conception, joined his own divine nature. ${ }^{115}$

In the first half of the sixth century, the Syriac bishop St. Severus, Patriarch of Antioch ( $† 538)$, sets forth that the stem of Jesse and David, who is Emmanuel, had sprouted and bore fruit in the ever virgin Mary, Mother of God, whose holiness the Scriptures talked about. ${ }^{116}$ Some fifteen years later the Byzantine poet and hymnographer St. Romanus the Melodist (c. 493-c. $555 / 565$ ) asserts that the Isaiah's prophecy announcing the emergence of a flower on the stem of Jesse foreshadows the supernatural conception of Jesus ("desirable bouquet from heaven") in the womb of the Virgin Mary. ${ }^{117}$

In this same sixth century, the views of Abraham of Ephesus, Cassiodorus, St. Gregentius and St. Gregory the Great are not very different. Thus, Abraham of Ephesus says that it is worth for Christians celebrate Mary as Mother of God and as Virgin, for having been made mother staying at the same time chaste, as it is foreshadowed by the stem emerged from the Jesse's root, from which the flower that perfumes the whole creation with pleasant odor sprang. ${ }^{118}$ And, while Cassiodorus (c. 485-C. 580) endorses the interpretation of the Isaiah's foretelling in the conventional sense that it symbolizes Christ, sprouted without sin from the Virgin as a beautiful flower, ${ }^{119}$ St. Gregentius (sixth century), in order to explain the sentence Erit in die illo radix Iessae, et qui surgit ad imperandum gentibus, wonders rhetorically who but the Virgin Mary, Mother of God, will be the root of Jesse, and who else but Jesus Christ, born of her, will be the one who arises to dominate the people. ${ }^{120}$

Meanwhile, the pope St. Gregory the Great (c. 540-604) confirms that the Isaiah's augury is explained by the fact that the one whom the Virgin conceived was not conceived by carnal human intervention, but by the Holy

\footnotetext{
115 Theodoretus of Kyros (Theodoretus Cyrensis), In Isaiam prol. PG 81, 311 C-D. In Alvarez CAMPOS 1976: IV/1, 449-450.

116 "Virga enim Iesse et Davidis, quae est Emmanuel, ut antea diximus, quae germinabit e sancta et Deigenitrice et semper virgine Maria, de qua sermo erat in scriptis tuae sanctitatis, vivida facta est et fructus protulit." (SEVERUS OF ANTIOCHIA, Epistula ad Theodosium Alexandrinum. In ALVAREZ CAMPOS 1979: vol. IV/2, 38-39).

117 "Flos Iesse exibit ex virga, ut a miro praenuntiatus est propheta: videmus enim Virginem supra naturam concipere ramum desiderabilem a coelo venientem, thronoque cum Patre potitum in altissimis." (St. ROMANUS THE MELODIST (ROMANUS CANTOR), Hymnus 13, 12 17. In AlVAREZ CAMPOS 1979: IV/2, 155).

118 "Dignum autem, fratres, celebrare Deiparam et Virginem. Et quis potest illam laudare? Dei enim mater effecta est, mater simul et innupta manet, (...) virga de radice Iesse, ex qua flos totam creationem grato delibuens odore effloruit (...)." (ABRAHAM OF EPHESUS, Oratio in festivitatem occursus. PO 16, 450-454. In Alvarez CAMPOS 1979: IV/2, 246-247).

119 "ex Virgine sine peccato tamquam pulcherrimi floris singulare decus emicuit; sicut Isaias dicit : 'Et flos de radice eius ascendet' (Is 11, 11)." (CASIODORUS, Expositio Psalmorum 27, 7. PL 70, 196. In Alvarez CAMPOS 1981: vol. VI, 227).

120 St. Gregentius Tafarensis, Disputatio cum Herbano Iudceo. PG 86, 692-693. In ALVAREZ CAMPOS 1979: IV/2, 267.
} 
Spirit's power. ${ }^{121}$ Shortly after St. Gregory expands the exegesis of the same prediction of Isaiah when he qualifies Mary with the biblical metaphor of the fertile mount that engenders an excellent fruit, that is, a new man, a metaphor that the holy Pontiff considers as similar to that of the flower sprout out from the stem in the root of Jesse. ${ }^{122}$

In the seventh century St. Isidore, archbishop of Seville (c. 556-636), in an exegetical treatise on Numbers, supports the unanimous interpretation of the Isaiah's prophecy, in the sense that the rod or stem symbolizes the Virgin Mary, who, without intercourse (sine humore [...] sine coitu), brought forth the flower, which is Christ, the Word of God. ${ }^{123}$ And in another polemic text against the Jews, the same sevillian prelate insists that the stem emerged from the Jesse's root is the Virgin Mary, sprout from the David's root, which begat the flower, which is Jesus Christ, the Savior. ${ }^{124}$

St. Ildefonsus (607-667), archbishop of Toledo, coincides with its illustrious predecessor to identify the Virgin Mary with the stem in the root of Jesse, which produced Christ as the flower with the single infusion of the Holy Spirit, without becoming corrupt with any carnal relationship. ${ }^{125}$

In the eighth century the Syrian theologian St. John Damascene (675-749), in a sermon on the Nativity of Mary, insists that "the stem [flourished in the Jesse's root] is the Virgin [Mary], ${ }^{126}$ of which, while preserving her virginity intact, sprang the flowery and perennial flower which is Christ." 127 And, in another passage of the same homily, the Damascene, after highlighting the doctrine of the Mary's virginal divine motherhood, praises her as "the stem, the branch of divine plantation, the only parturient between all the virgins,

121 “"Egredietur virga de radice Iesse et flos de radice eius ascendet (Is. 11,1).' (...) quia quem Virgo peperit non concepit materiali opere, sed Sancti Spiritus obumbratione." (ST. GREGORY THE GREAT, In Librum I Regum 1, 5. PL 79, 25-26. In Alvarez CAMPOS 1981: VI, 391).

122 "Sed recte mons frugifer dicitur de qua optimus fructus, id est novus homo, generatur; quam certe in fecunditatis suae gloria pulchram ornatamque propheta respiciens, ait: « Egredietur virga de radice Iesse et flos de radice eius ascendet (IS. 11,1) »." (Ibid.).

123 "Alii virgam hanc, quae sine humore florem protulit, Mariam Virginem putant, quae sine coitu edidit Verbum Dei; de qua scriptum est: 'Exiet virga de radice Iesse et flos de radice eius ascendet. (Is. 11, 1)'. Id est Christus, qui futurae typum praeferens passionis, candido fidei lumine et passionis sanguine purpurabat corona martyrum, gratia continentium." (ST. IsIDORE OF SEVILle, Quaestiones in Numeros, 15, 19. PL 83, 348 C. In Alvarez CAMPOS 1981: VI, 406).

${ }^{124}$ St. Isidore of SeVILLE, De fide Catholica contra Iudaeos 1, 9,7. PL 83, 466 B-C. En ALVAREZ CAMPOS 1981: VI, 407.

${ }^{125}$ ST. ILdEFOnSUS OF TOLEDO, Incipit libellus de virginitate Sanctae Mariae contra tres infideles. In ALVAREZ CAMPOS 1981: VI, 434-435.

${ }^{126}$ By identifying this stem or rod (virga) with the Virgin (Virgo), the Damascene makes here a suggestive play of words: "Virga Virgo est".

127 "Egredietur virga de radice Jesse, et flos de radice ascendit. Virga Virgo est, ex qua integro decore muliebri, floridus perennisque flos Christus assurgit." (ST. JOHN DAMASCENE, Homilia II In Nativitatem B.V. Mariae, 2. PG 96, 682). 
who, without intercourse, gave birth to the God of the universe and his Son as a flower". 128

Three and a half centuries later, St. Anselm of Canterbury ${ }^{129}$ (1033-1109) praises the Virgin Mary, Mother of God, as "the rod sprang in the Jesse's root", which made possible the new and unheard miracle of allowing that the Verb engendered by God the Father before all the centuries also become son of Mary, being at the same time God and man. ${ }^{130}$

Otherwise, the Cistercian Abbot Bernard of Clairvaux (1090-1153) stresses again and again with emphatic insistence, on this same Christological and Mariological exegesis on the Isaiah's prophecy. So, in a homily in praise of the Virgin Mary, St. Bernard states overwhelmingly that "in this testimony of Isaiah you must understand the Son [of God] as the flower and the mother [Mary] as the stem, because it flourished without seed and the Virgin conceived without male. And neither the flower's spring injured the stem's integrity, nor the sacred childbirth injured the Virgin's purity." ${ }^{131}$ Later on, in a first sermon for the Advent, Bernard completes with these poetic terms the agreed interpretation on the Jesse's root:

according to the prophet, a stem sprout from her, and a flower sprang from it, on which the Spirit of seven forms rested. The same prophet expressed that with more evidence in another place, saying: behold, a virgin shall conceive and bear a son, whose name is Emmanuel, which means God-with-us. Therefore, whom he calls first flower, later he calls Emmanuel; and whom he had called stem, later, speaking with more evidence, called her virgin. ${ }^{132}$

\footnotetext{
128 "Ave, virga, divinae plantationis ramus, sola inter omnes virgines puerpera, quae, nullo semine suscepto, universorum Deum et hierarcham Filium, uti florem emissisti." (Ibid.: 690).

${ }^{129}$ For a study of the philosophical, theological and moral doctrine of this Doctor of the Church, see Obras completas de San Anselmo (Introducción general y versión castellana por Julián Alameda), Madrid, La Editorial Católica, Col. Biblioteca de Autores Cristianos, 19521953, 2 vols.

130 "O beata Dei genitrix, virgo Maria, templum Dei vivi, aula Regis aeterni, sacrarium Spiritus sancti. Tu virga de radice Jesse, (...) cui novo et inaudito miraculo datum est ut Verbum quod ante saecula Deus genuit, fieret filius tuus, Deus et homo." (ST. ANSELM, Oratio LV, Ad eamdem sanctam Virginem Mariam. PL 158, 961).

131 "In hoc tamen Isaiae testimonio, florem Filium, virgam intellige Matrem, quoniam et virga floruit absque germine, et virgo concepit non ex homine. Nec virgae virorem floris laesit emissio, nec virginis pudorem sacri partus editio." (ST. BERNARD, In Laudibus Virginis Matris. Homilia II, 6. En Obras completas de San Bernardo. Edición bilingüe promovida por la Conferencia Regional Española de Abades Cistercienses, Madrid, La Editorial Católica, Col. BAC, 1984, Vol. II, p. 620).

132 "Ex his montibus prodiit, ut invenies, radix Iesse, unde, iuxta Prophetam, egressa est virga, et exinde flos ascendit, super quem requievit Spiritus septiformis. Quod manifestius alio in loco aperiens idem Proheta: Ecce, inquit, virgo concipiet et pariet filium et vocabitur nomen eius Emmanuel, quod interpretatur Nobiscum Deus. Quem enim prius florem, ipsum deinde Emmanuelem, et quam dixerat virgam, manifestius exprimens, virginem nominavit."
} 
And, in his second sermon on Advent, the abbot of Clairvaux once again confirms that the rod or stem flourished in the Jesse's root is the Virgin Mary, and the flower is her Son Jesus, whom he labelled as "a white and rosy flower, chosen from among a thousand; a flower which angels want to contemplate; a flower by whose fragrance the dead revive; and, as he himself testifies, is the flower of the field, not in garden." 133 Therefore, prior to establishing an eloquent wordplay between Virgo (the Virgin) and virga (rod or stem), in whose cusp the sublime holy (Christ) arises like a flower $-O$ Virgo, virga sublimis, in quam sublime verticem sanctum erigis! Usque ad sedentem in throno, usque ad Dominum maiestatis ${ }^{134}$-, St. Bernard concludes, somewhat apodictic:

I believe that with this it is clear who is the stem that springs from the root of Jesse, and who is the flower on which the Holy Spirit rests. Since the stem is the Virgin Mother of God; and his son is the flower. ${ }^{135}$

The Cistercian St. Amadeus, bishop of Lausanne (1110-1159), underwrites that the seed of God is revealed in all its magnificence and glory when, conceived in virtue of the Holy Spirit and born in the Jesse's root, flourished fully in the stem's top (Mary), thus becoming himself the flower. ${ }^{136}$ And in another passage, after asking that Mary, Queen of Heaven and mother of life. would be honored with frequent tributes, ${ }^{137}$ the prelate of Lausanne invites the

(St. Bernard, In Adventu Domini. Sermo Primus. De sex circunstantiis adventus, 11. In Obras completas de San Bernardo. Edición bilingüe (promovida por la Conferencia Regional Española de Abades Cistercienses, Vol. III. Sermones litúrgicos $\left(1^{\circ}\right)$, Madrid, La Editorial Católica, Col. BAC, 1985, p. 68).

133 "Flos utique Filius Virginis, flos candidus et rubicundus, electus ex millibus (Cantic. V, 10); flos in quem prospicere desiderant angeli, flos ad cuius odorem reviviscunt mortui, et sicut ipse testatur, flos campi est (Cant. II,1), et non horti." (ST. BERNARD, Sermones de Tempore. In Adventu Domini. Sermo II, 4. PL 183, 42).

${ }^{134}$ St. Bernard, En el Adviento del Señor. Sermón Segundo. In Adventu Domini. Sermo Secundus. In Obras completas de San Bernardo. Edición bilingüe promovida por la Conferencia Regional Española de Abades Cistercienses, vol. III. Sermones litúrgicos $\left(1^{\circ}\right)$, op. cit., p. 74.

135 "Ex his iam manifestum arbitror, quaenam sit virga de radice Iesse procedens, quis vero flos super quem requiescit Spiritus Sanctus. Quoniam Virgo Dei genitrix virga est, flos Filius eius." (Ibid.).

136 "Germen Domini in magnificentia et gloria exstitit, quando conceptum de Spiritu sancto, et ortum de radice Iesse in summitate virgae totum effloruit, imo flos fuit." (ST. AMADEUS OF LAUSANNE, Homilia III. In Amédée de Lausanne, Huit homélies mariales (Introduction et Notes par G. Bavaud. Texte latin établi par Jean Deshusses. Traduction par Antoine Dumas), Paris, Éditions du Cerf, Coll. Sources Chrétiennes, 1960, p. 98-100).

137 "Igitur coeli reginam, matrem vitae, fontem misericordiae, deliciis affluentem et innitentem super dilectum suum, sedulo celebremus officio, et laude licet impari 
believer to consider with attention that the Virgin, the most gracious stem sprung out of the Jesse's root, spread across the earth thanks to the wonderful development of its branches, in order to protect with its shadow the scattered Adam's children from the inclement weather, and nurture them in their hunger with its healthy fruit. ${ }^{138}$

A century later the Franciscan St. Bonaventure ${ }^{139}$ (c. 1217/21-1274), known as the Seraphic Doctor, highlights the miraculous savior events perceived by Isaiah, when he prophesized the flowering of the stem sprung up in the Jesse's root, a flower on which the Holy Spirit would rest. In his First Homily on the Annunciation of the Virgin Mary, St. Bonaventure maintains that this prophecy refers to Mary, which conceived God the Son, who since the very moment of his conception had in himself the presence of the divine Spirit in all his fullness. ${ }^{140}$ In the Seraphic's opinion, indeed, the words of Isaiah

designate this mystery [of the Lord's incarnation] under a triple metaphor: from the root, the shoot and the flower, giving us to understand three things: the nobility of her who conceives, the purity of the conception, the sublimity of the conceived Offspring. ${ }^{141}$

\section{Conclusions}

After the long and complex analysis of artistic images and doctrinal texts undertook in this essay, some conclusions are evident:

praedicemus." (ST. AmadeUS OF LAUSANNE, Homilia VIII. In Amédée de Lausanne, Huit homélies mariales, op. cit., p. 206.

138 "Feramur animis in sublime, intuentes diligentissime quod virga elegantissima orta de radice Iesse ramorum suorum mirabili extensione sese ubique terrarum expandit, ut dispersos filios Adae ab aestu, a turbine et a pluvia umbra desiderabili protegeret, fructuque saluberrrimo aleret esurientes." (Ibid.).

${ }^{139}$ Known as St. Bonaventure Fidanza or of Bagnoregio (by his surname Fidanza and by his birthplace Bagnoregio or Bagnorea), he was a Franciscan friar, whose order addressed as General Minister, before being appointed bishop and cardinal. By his influential philosophical, theological, ascetic and mystic teachings, he was declared Doctor of the Church, known as the Seraphic Doctor (Doctor Seraphicus).

140 "ipsa [María] concepit Filium, qui ab initio conceptionis habuit Spiritum septiformem in omnímoda plenitudine, sicut illud Isaiae undécimo: Egredietur virga de radice Iesse, et flos de radice eius ascendet. Et requiescet super eum spiritus Domini." (ST. BONAVENTURE, De Annuntiatione B. Virginis Mariae. Sermo II. In Obras de San. Buenaventura. Edición bilingüe, Tomo Cuarto, Madrid, La Editorial Católica, Col. BAC, 1947, p. 708).

141 "In praemissis igitur verbis Isaias hoc mysterium sub triplici metaphora designans, scilicet radicis, virgae et floris, tria nobis insinuat, scilicet nobilitatem concipientis, puritatem conceptionis, sublimitatem conceptae Prolis." (ST. BonaVenture, De Annuntiatione B. Virginis Mariae. Sermo I. En Obras de San. Buenaventura. Edición bilingüe, Tomo Cuarto, op. cit., p. 574). 
The stem of lilies, in the angel's hands or emerging from a jug or vase, is a frequent, almost constant, motif in the European late medieval images of The Annunciation. If this were not enough, the stem of lilies, converted in a nearly essential element in these pictures, takes over in them a highly visible role, with a remarkable size and a prominent place in the scene, as it was illustrated by the twelve Spanish Gothic paintings analyzed here.

Such repetitive and outstanding presence of the lilies' stem in these Annunciations allows us to conjecture that some symbolism of huge doctrinal importance underlies it.

The search for an explanation to such conjecture does not produce satisfactory findings in the literature specialized in symbols and iconographic motifs. The specialists we consulted, besides interpreting the lily in a generic and conventional sense -without essential link with the real meanings that this flower receives in the Annunciation-, do not justify with arguments the specific reasons why the lily symbolizes one or another of the alleged symbolism proposed by them: purity, virginity, innocence, Virgin Mary, Immaculate Conception, etc.

Furthermore, if the lily is the symbol of purity or virginity in general, this flower should appear in all -or in most of the - images of the saint virgins, a circumstance (the lily's presence) verified only in very few cases.

On the other hand, if the lily uniquely symbolizes the Mary's purity or virginity, this flower should be present in all or almost all the images of the Mother of Jesus. However, in addition to the fact that such circumstance is confirmed only rarely in other Marian scenes different to that of the Annunciation, the lily keeps in these images some theological meanings similar to those implied -in a primeval way - by the Annunciation.

The presence of the stem of lilies in the late medieval depictions of The Annunciation finds, ultimately, a satisfactory answer in a very long and strong patristic and theological tradition. Many Church Fathers and medieval theologians, indeed, coincide with emphasis on interpreting the Isaiah's foresight on the blossoming of a stem in the Jesse's root as a dual symbology, at the same time Mariological and Christological: for all of them this prophecy is an obvious metaphor for the virginal divine motherhood of Mary (who was identified as the stem sprout from the root) and the conception of Christ, the incarnate Son of God (who was identified as the flower sprang from the stem).

On this basis, the fact that the lily appears frequently with such prominence in most of these medieval pictures is justified because, by illustrating through art the seminal savior event of the Annunciation, the iconographic programmers of these images were inspired by the profuse and solid patristic and theological tradition that was able to see deep and core Mariological and Christological meanings in the flower sprang from a single stem. 
José María SALVAdOR GonZÁLEZ, Flos de radice Iesse. A hermeneutic approach to the theme of the lily in Spanish Gothic painting of The Annunciation from patristic and theological sources

\section{SOURCES AND BIBLIOGRAPHY}

\section{SOURCES}

ABRAHAM OF EPHESUS, Oratio in festivitatem occursus. PO 16, 450-454. In Alvarez CAMPOS 1979, vol. IV/2: 246-247.

Álvarez CAmpos, Sergio. Corpus Marianum Patrísticum. Burgos: Aldecoa, 1970-1981, 7 vols.

AMEDEE DE LAUSANNE, Huit homélies mariales (Introduction et Notes par le Chanoine G. Bavaud. Texte latin établi para Dom Jean Deshusses. Traduction par Dom Antoine Dumas), Paris, Les Éditions du Cerf, 1960, $240 \mathrm{p}$.

Biblia de Jerusalén. Nueva edición revisada y aumentada, Bilbao, Desclée de Brouwer, 1998, 1.895 p.

Biblia Sacra iuxta Vulgatam Clementinam. Nova editio (logicis partitionibus aliisque subsidiis ornata a Alberto Colunga et Laurentio Turrado). Madrid: La Editorial Católica, Col. Biblioteca de Autores Cristianos, 12 ${ }^{\mathrm{a}}$ edición, 2005, 1.255 p. + mapas s.p.

CASIODORUS, Expositio Psalmorum 27, 7. PL 70, 196. In Alvarez CAMPOS 1981, vol. VI: 227.

Eusebius of AleXandria, Sermo 10, de Christi nativitate. PG 86, 1, 367. In AlvarEZ CAMPOS 1979, vol. IV/2: 221.

Eusebius of CAesarea, In Isaiam, 53, 1. PG 24, 456 D. In Alvarez CAMPOS 1970, vol. I: 36.

GregOrIUS OF ElviRA, Tractatus Origenis 6, 36. In Alvarez CAMPOS 1974, vol. III: 72.

HeSiQuiUs of JeRUSALEM, Sermo in Annuntiationem. PG 93, 1460 D-1468 A. In Alvarez CAMPOS 1976, vol. IV/1: 566.

HesiQuiUs of JeRUSALEM, Sermo in Annuntiationem. PG 93, 1460 D-1468 A. In Alvarez CAMPOS 1976, vol. IV/1: 566.

Libro sobre la Natividad de María. Texto bilingüe latín / español. In SANTOS OTERO 2006: 238-252.

Migne, Jacques-Paul. Patrologiae Latinae cursus completus, Paris, Garnier, 217 vol. Quoted as PL.

Obras completas de San Anselmo (Introducción general y versión castellana por Julián Alameda), Madrid, La Editorial Católica, Col. Biblioteca de Autores Cristianos, 1952-1953, 2 vols.

Protoevangelio de Santiago. Texto bilingüe griego / español. In SANTOS OTERO, 2006: 130-170.

SANTOS OTERO, Aurelio de, Los evangelios apócrifos, Salamanca, La Editorial Católica, Biblioteca de Autores Cristianos, 148, 2006, 705 p.

SEVERUS OF ANTIOCHIA, Epistula ad Theodosium Alexandrinum. In AlvAREZ CAMPOS 1979, vol. IV/2: 38-39.

St. Ambrose, De benedictionibus Patriarcharum Liber Unus, 19. PL 14, 713.

ST. AmBrose, De Spiritu Sancto 2, 40. PL 16, 751. 
St. Amadeus Of LAUSANNE, Homiliae octo felicis memoriae Amedei Episcopi Lausannensis de Laudibus Beatae Mariae. In AMÉDÉE DE LAUSANNE 1960: $52-222$.

St. Amadeus of Lausanne, Sermo II. In AmÉdÉE De LausanNe 1960: 7497.

St. Amadeus of Lausanne, Sermo III. In AmÉdée de Lausanne 1960: 98100.

St. Amadeus of LausanNe, Sermo VI. In AmÉDÉE De LaUSANNE 1960: 178185.

St. Amadeus of Lausanne, Sermo VII. In Amédée de LausanNe 1960: 186-188.

St. Amadeus of Lausanne, Sermo VIII. In AmédÉE de Lausanne 1960: 189-206.

St. Anselm, Oratio LX. Ad sanctam Virginem Mariam in Assumptione ejus. PL 158, 965.

St. ANSELM, Oratio LIV, Ad sanctam Virginem Mariam. PL 158, 960-961.

St. ANSELm, Oratio LV, Ad eamdem sanctam Virginem Mariam. PL 158, 961.

St. ANSELM, Obras completas de San Anselmo (Introducción general y versión castellana por Julián Alameda), Madrid, La Editorial Católica, Col. Biblioteca de Autores Cristianos, 1952-1953, 2 vols.

St. BERNARD, Sermones de Tempore. In Adventu Domini Sermo II, 4. PL 183, 42-43.

St. Bernard, San Bernardo. Obras completas, Madrid, La Editorial Católica, Biblioteca de Autores Cristianos, 1953, 2 vols.

ST. BERNARD, Obras completas de San Bernardo. Edición bilingüe promovida por la Conferencia Regional Española de Abades Cistercienses, Madrid, La Editorial Católica, Col. Biblioteca de Autores Cristianos, 1983-1990, 8 vols.

St. Bernard, In Adventu Domini. Sermo Primus. De sex circunstantiis adventus, 11. En Obras completas de San Bernardo. Edición bilingüe..., op. cit., Vol. III. Sermones litúrgicos (1º), 1985: 68.

St. Bernard, In Adventu Domini. Sermo Secundus. In Obras completas de San Bernardo. Edición bilingüe..., vol. III, 1985: 74.

ST. BERNARD, In Laudibus Virginis Matris. Homilia II, 6. In Obras completas de San Bernardo. Edición bilingüe..., Vol. II. Tratados, 1984: 620.

St. BonaVenture, Obras de San. Buenaventura. Edición bilingüe, Madrid, La Editorial Católica, Col. Biblioteca de Autores Cristianos, 1947 ss, 6 vols.

St. Bonaventure, Obras de San Buenaventura. Edición bilingüe, Tomo IV. Teología mística, Madrid, La Editorial Católica, Col. Biblioteca de Autores Cristianos, 1947, vii, $975 \mathrm{p}$.

St. Bonaventure, De Annuntiatione B. Virginis Mariae. Sermo I. In Obras de San. Buenaventura, op. cit., 1947, vol. IV: 708-718.

St. Bonaventure, De Annuntiatione B. Virginis Mariae. Sermo II. In Obras de San. Buenaventura, op. cit., 1947, vol. IV: 752-764. 
St. Cromatius of Aquilea, Homilia in Mattheum 1, 6. In Alvarez Campos 1974, vol. III: 175-176.

St. EPHrÉm THE SYrian, Hymni de Nativitate 1, 17. In Alvarez CAMPOS 1970, vol. II: 477.

St. Fortunatus of Aquilea, Commentarii in Evangelia I. In Alvarez CAMPOS 1974, vol. III: 20.

St. Gregentius Tafarensis, Disputatio cum Herbano Iudceo. PG 86, 692693. In Alvarez CAMPOS 1979, vol. IV/2: 267.

Si. ILDEFONSUS OF TOLEDO, Incipit libellus de virginitate Sanctae Mariae contra tres infideles. In ALVAREZ CAMPOS 1981, vol. VI: 434-435.

St. ISIDORE OF SEVILLE, Quaestiones in Numeros, 15, 19. PL 83, 348 C.

St. ISIDORE Of SEVILle, De fide Catholica contra Iudaeos 1, 9,7. PL 83, 466 B-C. In Alvarez CAMPos 1981, vol. VI: 407.

St. Jerome, Commentariorum in Isaiam Prophetam Liber IV, 11. PL 24, 144.

St. Justin, Apologia I Pro Christianis, 32. PG 6, 379.

St. John Damascene, Homilia II In Nativitatem B.V. Mariae. PG 96, 682694.

St. Leo the Great, Tractatus 24, 1. PL 54, 203 C-206 A. In Alvarez CAMPOS 1981, vol. VI: 112.

St. MAXIMUS OF TURIN, Homilia XXXIX. PL 57, 310.

St. GREGORY THE GREAT, In Librum I Regum 1, 5. PL 79, 25-26. In AlVAREZ CAMPOS 1981, vol. VI: 391.

St. HipPOlYTUS Roman, De benedictionibus patriarcharum 1. In Alvarez CAMPOS 1970, vol. I: 61.

St. Hippolytus Roman, De Antichristo, 4. PG 10, 735 A. En Alvarez CAMPOS 1970, vol. I: 63.

St. Hippolytus Roman, In Gen 49, 9. In Alvarez CAMpos 1970, vol. I: 64.

St. Quodvultdeus, De Symbolo II, 4, 2-28. In Alvarez CAMPOS 1981, vol. VI: 51.

St. Romanus the Melodist (Romanus Cantor), Hymnus 13, 12-17. En ALVAREZ CAMPOS 1979, vol. IV/2: 155).

TheOdoretus OF Kyros, In Isaiam prol. PG 81, 311 C-D. In AlvareZ CAMPOS 1976, vol. IV/1: 449-450.

Tertullianus, Adversus Marcionem Liber III, 17. 3. PL 2, 344 C-345 A. In ALVAREZ CAMPOS 1970, vol. I: 169.

Tertullianus, Adversus Marcionem Liber V, 4. PL 2, 489.

Tertullianus, Adversus Marcionem 21, 5-7. PL 2, 785 B-789 B. In ALVAREZ CAMPOS 1970, vol. I : 183.

VorÁGINE, Santiago de la, La Leyenda Dorada (Traducción del latín: Fray José Manuel Macías), Madrid, Alianza Editorial, Col. Alianza Forma, 2930, 1990, 2 vols.

\section{BIBLIOGRAPHY}

Alcoy PedRós, Rosa, "Talleres y dinámica de la pintura del gótico internacional en Cataluña", en María del Carmen LACARRA DUCAY 
(Coord.), La pintura gótica durante el siglo XV en tierras de Aragón y en otros territorios peninsulares, Zaragoza, Institución Fernando el Católico (CSIC), Col. Actas Arte, 2007, p. 139-206.

BECKER, Udo, Enciclopedia de los símbolos, Barcelona, Swing, 2008, 446 p.

Biedermann, Hans, Diccionario de símbolos, Buenos Aires, Paidós, 1993 (1989), $573 \mathrm{p}$.

BRACONS, Josep and TRIADÓ, Juan-Ramón, La pintura española. Románico, Gótico, Renacimiento, Barcelona, Carroggio, Col. Arte Carroggio, 2000, $207 \mathrm{p}$.

CABROL, Fernand and Henri LECLERCQ, Dictionnaire d'Archéologie Chrétienne et de Liturgie, Paris, Letouzey et Ané, 1924-54, 12 vols.

Cirlot, Juan-Eduardo, Diccionario de símbolos, Barcelona, Labor, 1969 (1958), $495 \mathrm{p}$.

DAVY, Marie-Madeleine, "Lis", in Dictionnaire des symboles (sous la direction de Jean CHEVALIER, avec la collaboration d'Alain GHEERBRANT), Paris, Robert Laffont, 1969, p. 464-465.

Dictionnaire des symboles. Mythes, rêves, coutumes, gestes, formes, figures, couleurs, nombres (sous la direction de Jean CHEVALIER, avec la collaboration d'Alain GHEERBRANT. Conception et direction techniques: Marian Berlewi), Paris, Robert Laffont, 1969, 844 p.

Ferguson, George, Signos y símbolos en el arte cristiano, Buenos Aires, Emecé, 1956, 282 p.

Gudiol Ricart, José, Pintura gótica, vol. 9 de Ars Hispaniae. Historia Universal del Arte Hispánico, Madrid, Plus Ultra, 1955, 420 p.

Gudiol, Josep y Alcolea I Blanch, Santiago, Pintura gótica catalana, Barcelona, Ediciones Polígrafa, 1986, 494 p.

GUTIÉRREZ BAÑOS, Fernando, "La pintura gótica en la Corona de Castilla en la primera mitad del siglo $\mathrm{XV}$ : La recepción de las corrientes internacionales". In LACARRA DUCAY (Coord.) 2007: 86-138.

Hall, James, Diccionario de temas y símbolos artísticos (Introducción de Kenneth Clark), Madrid, Alianza Editorial, Col. Alianza Diccionarios, 1987 (1974), $329 \mathrm{p}$.

LACARRA DUCAY, María del Carmen, "Blasco de Grañén y la pintura del gótico internacional en Aragón”. In LACARRA DUCAY (Coord.) 2007: 7-72.

LACARRA DUCAY, María del Carmen, (Coord.), La pintura gótica durante el siglo XV en tierras de Aragón y en otros territorios peninsulares, Zaragoza, Institución Fernando el Católico (CSIC), Col. Actas Arte, 2007, 373 p.

LECLERCQ, Henri, "II. L'Annonciation dans l'art", Dictionnaire d'Archéologie Chrétienne et de Liturgie, Tome $1,2^{\mathrm{e}}$ Partie, Paris, Librairie Letouzey et Ané, 1924, col. 2255-2256.

MILLET, Gabriel, Recherches sur l'iconographie de l'Évangile aux XIV,$X V^{e}$ et XVI siècles d'après les monuments de Mistra, de la Macédoine et du Mont-Athos (Dessins de Sophie Millet), Paris, Éditions E. de Boccard, 1960, $2^{\mathrm{e}}$ édition, LXIV,809 $\mathrm{p}$. 
REAU, Louis, Iconographie de l'art chrétien. Tome Second, Iconographie de la Biblie. II, Nouveau Testament, Paris, Presses Universitaires de France, 1957, $765 \mathrm{p}$.

ReVILla, Federico, Diccionario de iconografia y simbología, Madrid, Cátedra. Col. Grandes Temas, 2012, $8^{\mathrm{a}}$ ed. (1990), 812 p.

SALVADOR GONZÁLEZ, José María, "La Virgen de la Anunciación, un paradigma de humildad en la doctrina y la imagen de la Edad Media", Mirabilia. Electronic Journal of Antiquity \& Middle Ages, $\mathrm{n}^{\circ}$ 15, julio-diciembre 2012, Institut d'Estudis Medievals, Universitat Autònoma de Barcelona, p. 189-220.

SAlVADOR GONZÁleZ, Ancilla et Regina. Aproximaciones a la iconografia mariana en la Edad Media, Saarbrücken, Editorial Académica Española, 2012, $236 \mathrm{p}$.

SALVADOR GONZÁlez, José María, "In virga Aaron Maria ostendebatur. Nueva interpretación del ramo de lirios en La Anunciación gótica española a la luz de fuentes patrísticas y teológicas", Anales de Historia del Arte, $\mathrm{n}^{\circ}$ 24, 2014, Madrid, Universidad Complutense de Madrid, p. 37-60.

SALVADOR GONZÁLEZ, José María, "Flos campi et lilium convalium. Tercera interpretación del lirio en la iconografía de La Anunciación en el Trecento italiano a la luz de fuentes patrísticas y teológicas", Eikón Imago, $\mathrm{n}^{\mathrm{0}} 5$, January-June 2014, Universidad Complutense de Madrid, p. 75-96.

SCHILLER, Gertrud, Iconography of Christian Art. Volume I (Translated by Janet Seligman), London, Lund Humphries, 1971, 475 p.

Silva MARoto, Pilar, "Pintura hispanoflamenca castellana. De Toledo a Guadalajara: El foco toledano". In LACARRA DUCAY (Coord.) 2007: 299334. 